OECDpublishing

REFERENCE

FRAMEWORK FOR

ASSESSING THE

SCIENTIFIC AND

SOCIO-ECONOMIC

IMPACT OF RESEARCH

INFRASTRUCTURES

OECD SCIENCE, TECHNOLOGY AND INDUSTRY POLICY PAPERS

March 2019 No. 65 


\title{
REFERENCE FRAMEWORK FOR ASSESSING THE SCIENTIFIC AND SOCIO-ECONOMIC IMPACT OF RESEARCH INFRASTRUCTURES
}

\author{
STI POLICY PAPER
}

This paper was approved and declassified by written procedure by the Committee for Scientific and Technological Policy (CSTP) on 21 March 2019 and prepared for publication by the OECD Secretariat.

Note to Delegations:

This document is also available on OLIS under the reference code:

DSTI/STP/GSF(2019)1/FINAL

This document, as well as any data and any map included herein, are without prejudice to the status of or sovereignty over any territory, to the delimitation of international frontiers and boundaries and to the name of any territory, city or area.

The statistical data for Israel are supplied by and under the responsibility of the relevant Israeli authorities. The use of such data by the OECD is without prejudice to the status of the Golan Heights, East Jerusalem and Israeli settlements in the West Bank under the terms of international law.

(C) OECD 2019

\footnotetext{
You can copy, download or print OECD content for your own use, and you can include excerpts from OECD publications, databases and multimedia products in your own documents, presentations, blogs, websites and teaching materials, provided that suitable acknowledgment of OECD as source and copyright owner is given. All requests for commercial use and translation rights should be submitted to rights@oecd.org.
} 


\section{Foreword}

This report follows and complements recent work by the OECD Global Science Forum on "The Impacts of Large Research Infrastructures on Economic Innovation and on Society" (2014), a case study of the European Organisation for Nuclear Research (CERN), and on "Strengthening the Effectiveness and Sustainability of International Research Infrastructures" (2017). The latter publication addressed the challenges faced by research infrastructure funders, managers and operators throughout the different phases of the research infrastructure life-cycle.

Research Infrastructures (RIs) represent an increasingly large share of research investment. Policy makers, funding agencies and RI management are increasingly expected to develop and adopt systematic and transparent procedures for making key decisions about implementing new projects or investing in existing ones.

This report proposes a "Framework for assessing the scientific and socio-economic impact of Research Infrastructures". It aims to provide funders, decision-makers and RI managers with a generic and versatile tool, based on current community practices, to evaluate the achievement of scientific and socio-economic objectives in a realistic way. This tool should facilitate the communication and reporting between different RI stakeholders.

The framework includes a list of Core Impact Indicators (CIIs), which can be used for most RIs whatever their type, discipline or life cycle phase, and which were identified through an in-depth survey of existing practices among RI managements and RI stakeholders (local and national authorities, funders, RI hosts). The CIIs are complemented by a more detailed list of standard indicators which can supplement these CIIs as needed. Information on how to use the framework is provided at the end of this report.

This report was co-written by the GSF Expert Group chair Vincent Mangematin, GSF consultants Frédéric Bally and Jean Moulin and the GSF secretariat (Frédéric Sgard), with extensive input from Expert Group members.

We hope that this report will be informative and useful and we would be interested in receiving comments from readers. The Global Science Forum staff can be contacted at gsforum@oecd.org. 


\section{Table of contents}

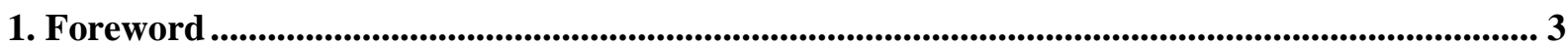

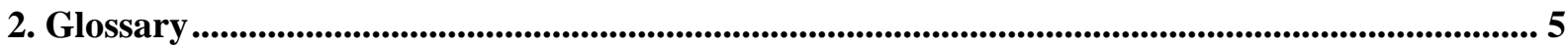

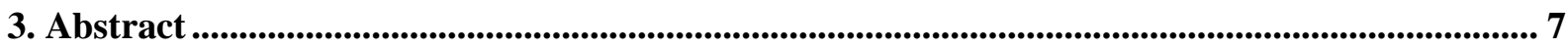

4. Executive Summary .................................................................................................................................. 8

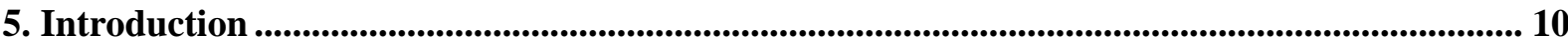

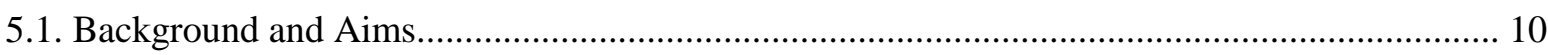

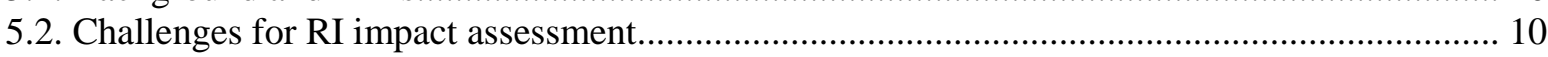

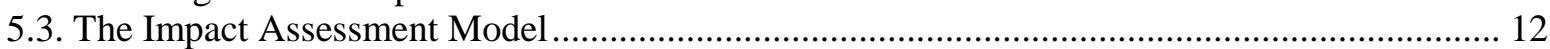

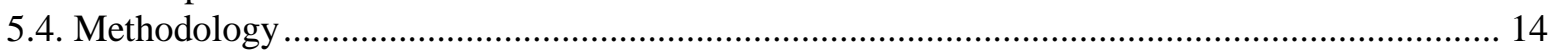

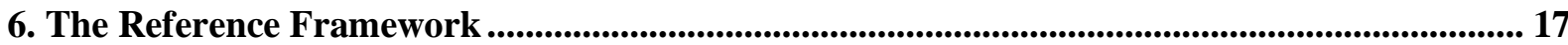

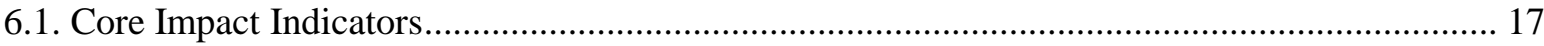

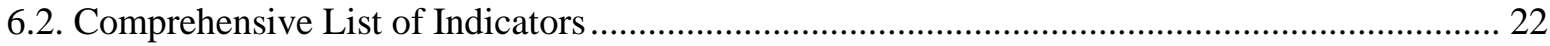

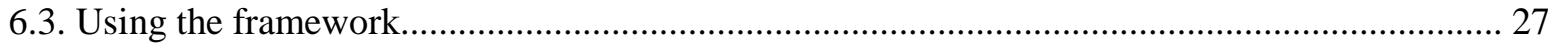

7. Conclusions ......................................................................................................................................................... 35

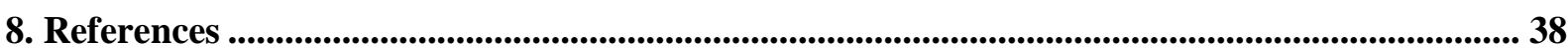

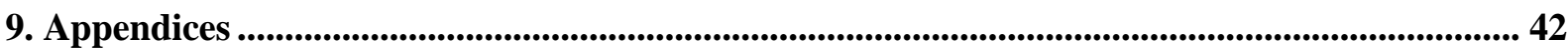

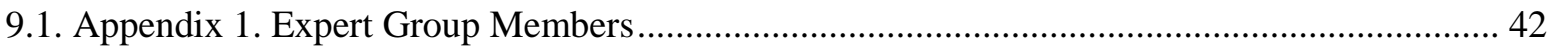

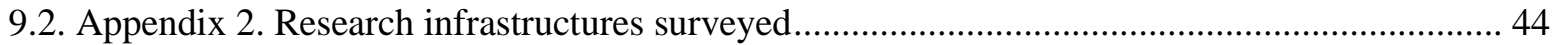

9.3. Appendix 3. Core Impact Indicators and their relevance according to RIs' lifecycle and types 46

9.4. Appendix 4. Indicators sorted by strategic objectives ............................................................... 49 


\section{Glossary}

Key terms as they are used in this document are defined below.

Continental: Refers to one of the large "world regions" (e.g. Europe, North America, Eastern Asia, etc.).

Core Impact Indicators (CIIs): Limited group of impact indicators that provide a general picture of the socio-economic impact of a RI. They are often more generic than other indicators as they need to be more versatile. CIIs can be used by most RIs, whatever their structure, role and scientific domain. They can be integrated into Key Performance Indictors (KPIs) to better manage RI activities and to include impact assessment in regular management and decision-making processes.

Economic impact: The economic impact refers to the direct and indirect economic activities and returns created by the RI or its presence at a defined scale.

Lifecycle phases: The different phases of a RI's lifecycle, i.e. preparatory, construction, operation, upgrade and decommission.

Impact: Intended and unintended effects of the RIs' activities and outputs over its lifecycle.

Impact pathway: An impact pathway is a mechanism by which causal links between inputs, activities, outputs and outcomes, and their intended impacts can be mapped.

Indicator: Quantity or value of a RIs' activities and outputs, which provides an indication of its impact. Indicators are a way to measure if the intended outcomes have been realised/achieved. An indicator relies on being able to collect adequate data to be meaningful.

Input: These are the resources mobilised by the RI to perform its activities relatives to an objective. Resources may come from multiple sources and include in-kind support.

Key Performance Indicators (KPIs): KPIs are project-management tools used to monitor the performance of an RI, vis-à-vis its objectives and the efficient use of resources. They may include a diversity of indicators including many that are not directly linked to impact (for example on how the budget is respected, on safety records, etc.).

Local: Immediate geographical area around an RI, i.e. an administrative region.

Mission of an RI: The mission defines the purposes and activities of an RI, the services and products delivered and which communities of users are served. The mission is normally described in the statutes of an organization and provides the framework or context within which the RI's strategy and strategic objectives are formulated.

Output: RI's products attributable to an activity. In this document, outputs are considered as deliverables that help fulfil strategic objectives.

Qualitative indicator: People's perceptions and judgements on a selected topic. Qualitative indicators are non-numerical and are assessed through case studies, surveys and in-depth interviews.

Quantitative indicator: Measure of quantities or amount based on objective and available data. Quantitative indicators can be a number, an index, a ratio or a percentage. 
Regional: Refers to one or several administrative/geographical subnational entities within the territory of a country or partly covering several neighbouring countries.

Research Infrastructure (RI): An organisational structure dedicated to facilitate or conduct research, provide scientific equipment, data or services for use in basic or applied research.

Scoreboard: Graphical representation of the progress over time of the RI toward a specified goal. Scoreboards can be used to track performance indicators and are designed to provide a framework to manage resources.

Social and societal impact: The effect of the RI's activity respectively, on the social fabric and well-being of communities, individuals and families, and on society as a whole.

Strategic objective of a RI: The strategic objectives are what a RI aims to achieve in the medium or long-term future. Strategic objectives guide current and future courses of action.

Structuring effects: The effects of the RIs' activity on networking, collaborations, community building, etc. 


\section{Abstract}

Research Infrastructures (RIs) are indispensable for enabling and developing research in almost all scientific domains and represent an increasingly large share of research investment. As policy makers, funding agencies and RI management are increasingly expected to justify key decisions about implementing new projects or investing in existing ones, there is a demand for credible methodologies for assessing the overall impact of RIs.

This report proposes a "Framework for assessing the scientific and socio-economic impact of research infrastructures". It aims to provide funders, decision-makers and RI managers with a generic and versatile tool, based on current community practices, to evaluate the achievement of scientific and socio-economic objectives in a realistic way. The framework can be adapted for different types of RIs and different stages in the RI lifecycle. This tool should facilitate the communication and reporting between different RI stakeholders.

Keywords: research infrastructures, scientific impact, socio-economic impact, impact assessment. 


\section{Executive Summary}

Research Infrastructures (RIs) are organisational structures dedicated to facilitating or conducting research, providing scientific equipment, data or services for use in basic or applied research.

Although RIs are designed to support research needs, their impact goes beyond the production of scientific results and knowledge. Their conception, construction and operation can involve and require unique technological developments, data management systems and highly-skilled staff. RIs offer opportunities for innovation and market development, can attract investments and contribute broadly to socio-economic development. In some cases they can constitute a focal point for the development of an innovation ecosystem.

Because RIs are largely funded by public resources, there is a logical demand for understanding and evaluation of the return on investment of these facilities to support informed decision-making. Furthermore, while impact assessment represents an investment in terms of financial cost and human resources, it also provides RI management with useful information for negotiations with funders. However, socio-economic impact is difficult to assess using conventional methodologies. RIs are extremely diverse, and can have a very broad range of direct and indirect impacts, which themselves will vary along the life cycle of the RIs.

This report proposes "A Reference Framework for assessing the scientific and socio-economic impact of Research Infrastructures", i.e. a tool to help RIs of different scale, types and at different steps of their lifecycle, to assess the impact of their activities.

The focus of this framework is impact assessment and not performance evaluation. These terms overlap but are distinct: performance relates to the efficient use of resources; impact relates to the transformative effect of an RI. The Reference Framework prioritises impact assessment even though performance and impact can be linked, and some of the impact indicators can be used by RI management to evaluate performance [i.e. and may even be considered as Key Performance Indicators (KPI)].

A single framework cannot cover all types of impacts and include every existing indicator. The proposed tool includes a subset of indicators based on community consultation. It is flexible and should be adapted (and even expanded) to address the specific needs of a particular RI.

Two indicator categories are included in the framework:

- Core Impact Indicators (CIIs): this is a restricted list of indicators which can provide a general picture of the socio-economic impact of an RI at a given time.

- A more complete list of standard indicators. These indicators are representative of what is traditionally used by the RIs surveyed during this work and have been partially reworked to be more standard and generic.

Each RI can define with its stakeholders the indicators which are most relevant for its particular situation and specific missions.

A number of considerations have to be taken into account for an optimal use of this assessment framework:

- The link between strategic objectives and indicators is one of the major contributions of this work: The aim is it show how an RI achieves its goal through its whole set of activities. 
- Although this report provides a number of representative indicators commonly used by RIs, none of these are mandatory. Each indicator should be carefully selected and adapted, as necessary, to the RI objectives and context, and the framework itself can be adapted and expanded as required.

- This framework is not designed for direct comparative assessment of different RIs. Even similar types of RIs may have different strategic objectives and missions and socio-economic impact is context-specific.

- Impacts often results from cumulative effects over time. As indicators usually only provide snapshot information at a given time, a more precise impact assessment can be generated by pooling data series, hence the need to use consistent indicators over time.

- Quantitative indicators, which constitute the majority of indicators included in this framework, can only provide a partial view of impact. They should be complemented whenever possible with more qualitative indicators and narratives which can help illustrate the diversity of impacts generated by each RI.

Based on the findings of this work, the following recommendations are proposed for various RI stakeholders:

- RI communities are encouraged to adopt and refine this assessment framework as a basis for impact assessment. They should seek consensus on the indicators which are most relevant for their RIs (and co-design new indicators if required) and on the specific data that could best inform each indicator.

- RI management should define early in the RI life-cycle, their impact assessment framework and its future uses. Definition of data sources and collection processes is an important aspect of this as consistent data series are important for accuracy.

- RI stakeholders are invited to work with RI managers to define their needs for specific indicator data as well as the use in decision-making processes. Feasibility of data collection is an important consideration during this 'co-design' process. Where necessary (e.g. for small and medium-size RIs), funders should provide the necessary support for the data collection required to conduct robust impact assessment exercises. 


\section{Introduction}

\subsection{Background and Aims}

Research Infrastructures (RIs) are long-term enterprises, often operating for several decades. They represent strategic investments which are indispensable for enabling and developing research in almost all scientific domains, and play a major role in innovation and science (Jacob and Hallonsten, 2012; Hallonsten and Heinze, 2012; Hallonstein, 2014). RIs have a societal value and their impacts are not limited to fostering scientific knowledge for the benefit of scientists; they also impact their environment socially and economically.

RIs represent an increasingly large share of research investment, and policy makers, funding agencies and RI management are increasingly looking for systematic and transparent procedures for making key decisions about implementing new projects or investing in existing ones. Furthermore, the willingness of the policy-makers and taxpayers to support RIs is partially based on their expected societal value (Florio and Sirtori, 2014). Hence, there is a demand for credible methodologies for assessing the socio-economic impact of RIs (Hallonsten and Christensson, 2017).

In 2014, the Global Science Forum (GSF) set up an Expert Group to examine potential priorities for RI policy that should be addressed at the international (global) level. One of the top priorities was the development of a framework for assessment of the impact of research infrastructures. To explore this further, an international workshop was organised in 2015 in Paris. The scientific and policy experts attending this workshop underlined the need for a common approach to impact assessment, with the understanding that evaluation of scientific, economic and social impact should be addressed in a consistent way. A project to develop "A Reference Framework for assessing the scientific and socio-economic impact of Research Infrastructures" was therefore initiated in 2016 and carried out by a group of international experts nominated by interested national delegations (Appendix 1).

The objective of the Reference Framework presented in this report is to provide RI managers and stakeholders with a versatile tool, based on current community practices, to help in the selection of indicators and collection of data that is necessary to evaluate the achievement of scientific and socio-economic objectives in a realistic way. The framework can be adapted for different types of RI (distributed, single-sited, virtual, etc.) and different stages in the RI lifecycle (preparatory, construction, operation, etc.). What this framework does not include, is specification of detailed methodologies to analyse collected data, which was beyond the scope of the study.

\subsection{Challenges for RI impact assessment}

Each RI has its own objectives and performs specific activities. Their impact cannot always be assessed solely in traditional ways - with an exclusive focus on scientific activities or financial return on investment. A report from the Rathenau Institute's (Horling et al., 2012) emphasised the difficulty of identifying adjunctive societal impact for big science facilities using traditional methodologies such as cost-benefit analysis, which have been used on some large RIs (BianchiStreit et al., 1984; Cost Office, 2010; Drèze and Stern, 1987; Gramlich, 1994; SWQ Consulting, 2007; Florio et al., 2016). Although large-scale RIs do show evidence of the creation of networks and communities, social impact is difficult to quantify. Traditional impact assessment methodologies often have a limited scope and they require considerable expertise and resources. 
Such assessments tend to involve a lot of $a d$ hoc data collection. They are usually retrospective and non-periodical (they are performed on request).

In Europe, the European Strategy Forum on Research Infrastructures (ESFRI) is encouraging the development of a related framework model that could provide comparisons between different types of RIs "while recognising the great diversity in scientific domains and characters, the wide range of benefits they bestow on society, and different national environments" (ESFRI, 2017). Whilst such comparisons may be intuitively attractive, it was recognised by the expert group that, even in the same field of science, creating a standard model allowing comparison between RIs would be extremely challenging. The Reference Framework proposed here is therefore not designed for comparative assessment of different RIs.

To assess the impacts of RIs, indicators need to be determined that can be used as proxies for various types of impact. Defining (and communicating) these indicators can be a way for different stakeholders to build a common vision and objectives Indicators may then be used both for internal management and for reporting to external stakeholders.

Table 1. Stakeholders' interests in RI impact assessment

\begin{tabular}{|c|c|}
\hline Interested stakeholders & Main interest \\
\hline National authorities & $\begin{array}{l}\text { Justify large investment to finance ministry and to other } \\
\text { political authorities (parliament...). Demonstrate, maintain or } \\
\text { develop leadership and attractiveness at national/international } \\
\text { level. National authorities are usually interested in a limited } \\
\text { number of generic indicators which provide an overall picture } \\
\text { of the impact, in particular the "scientific and economic return } \\
\text { on public investment". }\end{array}$ \\
\hline Regional/local authorities & $\begin{array}{l}\text { Justify investment; increased attractiveness of the area; } \\
\text { benefit to local businesses and the development of } \\
\text { local/regional innovation ecosystems; raise attractiveness and } \\
\text { quality of local higher education institutions. }\end{array}$ \\
\hline RI funders & $\begin{array}{l}\text { Value for money; maximise return on investment. Top priority } \\
\text { is usually the scientific and technological impact but funders } \\
\text { often require Rls to demonstrate additional benefits. }\end{array}$ \\
\hline $\mathrm{RI}$ initiators (individuals and institutions at the origin of the RI) & $\begin{array}{l}\text { Ex ante assessment to demonstrate potential impact for } \\
\text { funders, national authorities and local authorities and help } \\
\text { raise funding. }\end{array}$ \\
\hline RI management & $\begin{array}{l}\text { Monitor impact on a regular basis to improve performance and } \\
\text { gather information to make the case to funders when upgrades } \\
\text { are required. }\end{array}$ \\
\hline RI hosts & $\begin{array}{l}\text { Demonstrate the value of the } \mathrm{RI} \text { in terms of scientific } \\
\text { attractiveness, training and education. }\end{array}$ \\
\hline Scientific community & $\begin{array}{l}\text { Advocate for new (ex ante assessment) or updated Rls to } \\
\text { foster new scientific knowledge and developments. }\end{array}$ \\
\hline Civil society/general public & $\begin{array}{l}\text { Value for money, new scientific knowledge, general benefit to } \\
\text { society (e.g. health, energy, environmental topics). On case by } \\
\text { case basis, impact on the environment and/or on local } \\
\text { populations. }\end{array}$ \\
\hline
\end{tabular}


Assessing the impact of RIs is challenging for several reasons:

- RIs' raison d'être is to deliver quality services that facilitate cutting edge science to the scientific community. Impact is difficult to fully evaluate as many outcomes are indirect and not directly produced by the RI itself but rather by its users.

- RIs have multiple stakeholders with different strategic visions and objectives, and even similar RIs may have different mission statements. There are also different expectations from different audiences (see Table 1).

- Research outcomes can be uncertain and non-linear. In addition scientific results may be dependent on more than one RI. Therefore, it can be difficult to assess the specific effects of the knowledge produced within a specific RI.

- Research is subject to time lags: there can be a long time between an experiment and a discovery, and even a longer time between a discovery and its application in society. This is especially true for curiosity-driven basic research.

- RIs' socio-economic impact is both direct and indirect (via causal chains), can include many different elements (capacity building, attractiveness for a local area, etc.) and may be cumulative (impact may increase over time).

- RIs are extremely diverse and their impact may change during their lifecycle (see appendix 3); this needs to be accounted for when deciding prospectively on indicators.

- Societal impacts may be very broad and may be difficult to capture. There are also societal impacts derived from scientific, technological and economic outputs as well as dedicated outreach and education activities.

The Reference Framework proposed in this report addresses these challenges, by providing a consensus set of commonly used and reportedly useful indicators.

\subsection{The Impact Assessment Model}

The philosophy at the outset underpinning the development of the Reference Framework is the following:

- While high quality scientific output remains the most important strategic goal of all RIs, their socio-economic impact is broader. It includes cultural, educational, economic and social impact as well as structuring effects of the RI. The Reference Framework addresses this broader scope.

- Potential users of the Reference Framework are both RI management wishing to monitor the impact of their facility and external stakeholders interested in evaluating RI impact for a variety of objectives.

- Impact assessment must be connected to the strategic objectives and mission of each RI.

- To be useful, indicators have to be easy to measure or easy to collect, user-friendly, reliable and meaningful. Comparable data should ideally be collected over several years in a consistent manner in order to compare progress over time.

- Economic impacts indicators are practical and selected from among commonly recognised indicators (induced turnover, innovation, start-ups, direct and indirect employment, etc.). 
- Social/societal impact indicators are more difficult to design and to interpret and require more in-depth validation or coupling with narratives.

Performance evaluation and impact assessment are not identical: Performance relates to the efficient use of resources. Impact relates to the transformative effect of an RI. The Reference Framework prioritises impact assessment even though performance and impact can be linked and some of the impact indicators can be used by RI management to evaluate their RI's performance.

A single framework cannot cover all types of impacts and include every existing indicator. The proposed tool includes a subset of indicators based on community consultation. It is flexible and should be adapted (and even expanded) to address the specific needs of any particular RI.

\section{Indicators as proxies for impact}

In the impact assessment framework, indicators are determined as a means to evaluate RI impacts. Data to implement the indicators proposed in this framework may be drawn from inputs, activities or outputs (see Figure 1).

Figure 1. The logic model - how to measure impacts

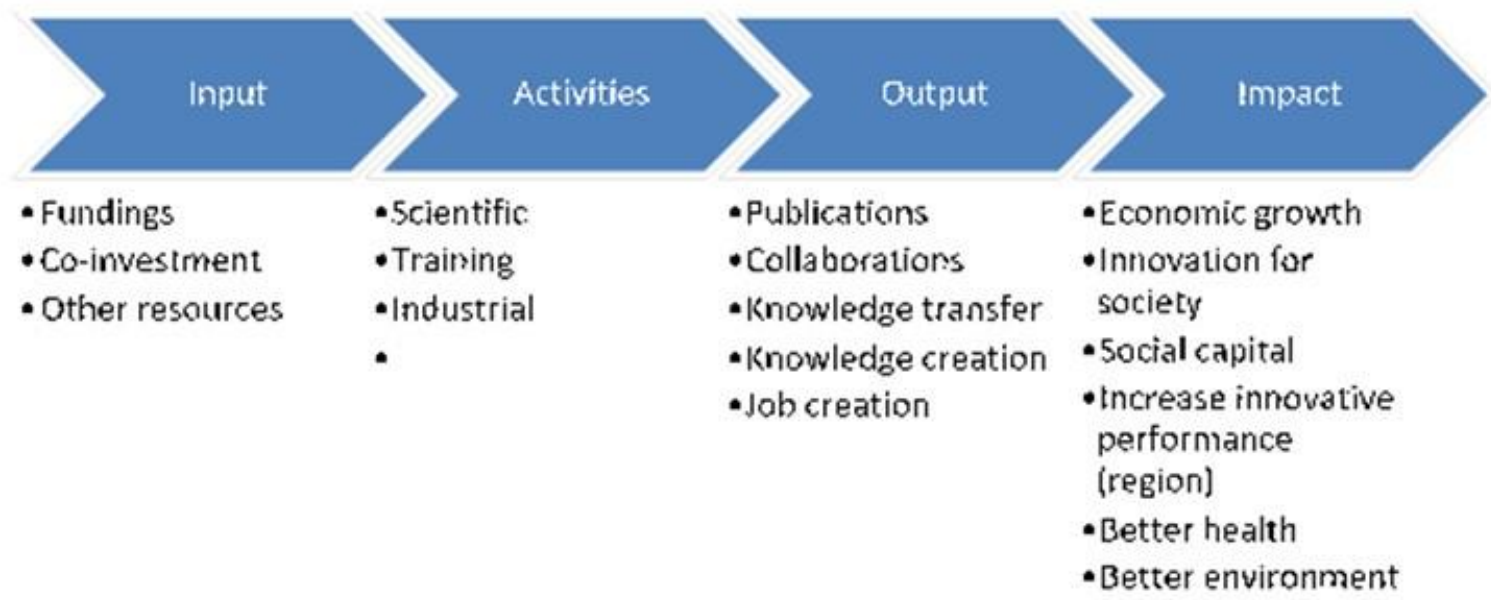

Source: Adapted from CSIRO (Barratt, Wang and Binney, 2016).

- Inputs: These are the resources mobilised by the RI to perform its activities. Resources may come from multiple sources and in-kind support can be an important input.

- Activities: These are what RIs do. They are enabling science and technology, they may have targeted economic and social activities and they also develop the skills and competencies of human resources.

- Outputs: These are the results of RI activities: scientific, educational, collaborative and economic. 
- Impacts: Intended and unintended effects of the RIs' activities and outputs over its lifecycle. Activities and outputs can lead to long terms impacts on different aspects of society and the economy

\subsection{Methodology}

To identify relevant indicators, common practices and information on the evolution of impact assessment methodologies, the expert group first conducted an extensive literature review. This revealed that a large diversity of methodologies were being used, mostly on a case by case basis, but did not provide consistent information on the rationale for the use of the different indicators and methods. The expert group therefore carried out surveys to obtain more detailed information on the current practices and stakeholder expectations. Case studies were then conducted to validate the information obtained during the surveys in different contexts.

\section{Surveys}

Two in-depth surveys [see https://community.oecd.org/docs/DOC-146803 and https://community.oecd.org/docs/DOC-146804] were carried out using detailed questionnaires followed by extensive interviews to gather information on the impact assessment practices of RIs. The first survey was conducted among RI managers and the second among RI stakeholders (funders, governments, local authorities, RI host institutions), selected for their representativeness. Management from 21 RIs and stakeholders from 13 of these RIs were included in this study. RIs included were of different types (distributed, single-sited, virtual, etc.), at different stages of their lifecycle (preparatory, construction, operation, etc.), and covering different scientific domains (social science, natural science, physics, etc.), to ensure that the framework model would be as generalizable as possible. The in-depth surveys were aimed at identifying indicators and data that are routinely collected/planned, their periodicity and their use and purposes. The perceived usefulness of each indicator and relevance to the various lifecycle phases of an RI were also explored. The aim was to build a picture of existing RI practices in terms of impact assessment and to identify potential gaps and needs. The RIs surveyed and the summarised results of this study are detailed in Appendix 2.

The proposed Reference Framework includes the indicators which RIs used and have found useful. The first version of the framework was submitted to an expert panel to get feedback during a workshop which was organised in Paris on 19-20 March 2018. This workshop brought together about 50 participants, RI managers, and other stakeholders including government representatives from 15 countries and experts from various institutions, who, in addition to their comments and feedback, presented their own assessment practices.

\section{Case studies}

Following the workshop, the updated version of the framework was then tested in a small number of case studies. Four RIs were surveyed through a combination of face to face interviews completion of a questionnaire [https://community.oecd.org/docs/DOC-146802] and complementary documentation relevant to impact assessment for these RIs. 
The four test cases were:

- European Spallation Source (ESS) in Lund (Sweden)

- Centre for Interdisciplinary Research in Music Media and Technology (CIRMMT) at Mc Gill University in Montreal (Canada)

- Inter-university Microelectronics Centre (IMEC) in Leuven (Belgium)

- Biobanking and Biomolecular Resources Research Infrastructure (BBMRI) in Graz (Austria).

These case studies were helpful for finalising the framework and some of the lessons learned are presented in this document. Contributions from John Womersley (ESS), Isabelle Cossette (CIRMMT), Helga Deschrijver (IMEC) and Michaela Mayrhofer (BBMRI) in particular are kindly acknowledged.

\section{Categorisation of indicators}

As a result of the literature analysis, survey results, workshop feedback and discussion with experts, relevant indicators were organised according to two separate approaches:

- The first approach articulates indicators with strategic objectives, as identified by stakeholders and managers during this study. Strategic objectives can contribute to a common understanding between the RI and its various stakeholders. Strategic objectives can directly influence how RIs impact society. They also often determine the allocation of resources and priorities.

We chose to select six standard objectives that emerged from the consultations and to add one on social responsibility. ${ }^{1}$ These cover all the main dimensions of impact (science, technology, economy, social, societal, education):

i. be a national or world leading scientific RI and an enabling facility to support science

ii. be an enabling facility to support innovation

iii. become integrated in a regional cluster/in regional strategies/Be a hub to facilitate regional collaborations

iv. promote education outreach and knowledge transfer

v. provide scientific support to public policies

vi. provide high quality scientific data and associated services

vii. assume social responsibility towards society.

Additional strategic objectives were also mentioned by a few respondents. These included for example Promoting international relationships and global diplomacy through science collaborations ("Science diplomacy") but were not universal enough to be included in the standard framework. The respondents to the questionnaire and interviewees also underlined the importance of the structuring effects of their research infrastructure (increased collaborations between institutions, creation of user communities across disciplines, etc.).

Considering the specific nature of this element, we did not include it as a strategic objective nor an impact category in the framework model, but rather integrated it as a Core Impact Indicator in relation to the enabling role of RIs. However, RI management could select structuring effects as a specific strategic objective if it is very important for them. Indeed, 
this list can be adapted for each RI according to the vision and objectives. The seven strategic objectives are not mutually exclusive and any single RI is likely to have more than one although is unlikely to have all seven.

- The second approach lists indicators by main impact categories. This is a more traditional way to articulate indicators, and was the initial approach that was used in the surveys. Six commonly used categories were employed: scientific impact; technological impact; training and education; direct economic impact; indirect economic impact and societal impact.

Most of the indicators identified are applicable to a large proportion of RIs regardless of their type (e-infrastructure, distributed RI, observational RI, etc.) or discipline. However, adjustments may be necessary to adapt indicators to the lifecycle phase of an RI. ${ }^{2}$

\section{Indicator relevance}

The indicators described in the following chapter are not necessarily perfect proxies for the impact to be analysed. For example, patent numbers only partially reflect technological impact, and a better indicator might be the actual use of licences. Similarly, the number of spin-off companies generated is not a great indicator of economic impact (many new companies will fail) and better indicators could be imagined that measure turnover. However, one of the primary criteria which drove this project was feasibility of implementation. The indicators proposed are those which are already in use by many RIs, for which data are often collected or available, and which are, for better or worse, recognised as useful by many of the RI stakeholders. This framework does not attempt to propose an ideal list of impact indicators, but rather selects a restricted list of already existing indicators that can be effectively used.

Because the selection of indicators is based on established practices it is also important to note that impact indicators should not be interpreted on the basis of single figures. It is usually preferable to evaluate progress on the basis of trend data. 


\section{The Reference Framework}

The impact assessment framework takes into account the main activities of RIs and approaches the impact through proxies, which can be inputs, outputs or even activities themselves (Figure 1). For example, the number of publications in high impact journals may be a proxy for international scientific impact, the number of patents with commercial use may be a proxy for the role of the RI in innovation, and the number of staff may be a proxy for the impact on the local economy.

This framework includes two indicator categories:

- A list of $\mathbf{2 5}$ Core Impact Indicators (CIIs): this is a restricted list of indicators considered as representative and which can provide a general picture of the socioeconomic impact of an RI at a given time.

- A more complete list of $\mathbf{5 8}$ standard indicators (25 CIIs and 33 additional indicators). These indicators are representative of what is traditionally used by the RIs that were surveyed and have been partially reworked to be more standard and generic.

\subsection{Core Impact Indicators}

Core Impact Indicators (CIIs) are generic indicators that can provide a general picture of the impact at a given time and that can be used by most RIs whatever their type and discipline. CIIs were identified and validated through our surveys, discussion with stakeholders and literature.

Each RI can define with its stakeholders the CIIs which are the most relevant for its current situation. The CIIs are complementary - and can be integrated into KPIs to better manage $\mathrm{RI}$ activities and to include impact assessment in regular decision-making processes. CIIs are relevant for assessing the development of an infrastructure over time and in relation to strategic objectives.

The list of CIIs presented in Table 2 is organised in line with the seven common strategic objectives described earlier (see 5.4). Each indicator is identified with a unique number and a letter (referring to its field of impact), in order to be more easily traceable across each of the various tables presented in this report (Letter signification: S: Scientific impact; T: Technological impact; E: Economic impact; H: Training and education impact; $\mathrm{O}$ : Social and societal impact). More detailed information on each of these indicators is given in Table 4. 
Table 2. Core Impact Indicators, sorted by strategic objectives

\begin{tabular}{|c|c|c|}
\hline Standard Objectives & $\begin{array}{c}\text { Core Impact } \\
\text { Indicators } \\
\end{array}$ & Data \\
\hline \multirow{7}{*}{$\begin{array}{l}\text { Be a national or world scientific } \\
\text { leading RI and an enabling } \\
\text { facility to support science }\end{array}$} & \multirow{2}{*}{$\begin{array}{l}\text { S2-Number of } \\
\text { citations }\end{array}$} & \multirow[b]{2}{*}{$\begin{array}{l}\text { Total number of citations received by } \\
\text { publications. May include: authors } \\
\text { from the RI or using the RI }\end{array}$} \\
\hline & & \\
\hline & $\begin{array}{l}\text { S3-Number of } \\
\text { publications in high- } \\
\text { impact factor } \\
\text { journals }\end{array}$ & $\begin{array}{l}\text { Number of publications from RI users } \\
\text { published within Q1 journals }{ }^{3}\end{array}$ \\
\hline & $\begin{array}{l}\text { S4-Number of } \\
\text { projects granted }\end{array}$ & $\begin{array}{l}\text { Number of projects funded by } \\
\text { external grants (may be divided into } \\
\text { user or discipline categories) }\end{array}$ \\
\hline & $\begin{array}{l}\text { S6-Number of } \\
\text { scientific users }\end{array}$ & $\begin{array}{l}\text { Number of users, Discipline } \\
\text { distribution, Top scientific users, } \\
\text { Nationality distribution }\end{array}$ \\
\hline & $\begin{array}{l}\text { S9-Collaboration } \\
\text { excellence } \\
\text { (scientific) }\end{array}$ & $\begin{array}{l}\text { Total number of applications for } \\
\text { using the RI } \\
\text { Total number of applications from } \\
\text { world leading teams }\end{array}$ \\
\hline & $\begin{array}{l}\text { S10-Structuring } \\
\text { effects }{ }^{4} \text { of the RI on } \\
\text { the scientific } \\
\text { community }\end{array}$ & $\begin{array}{l}\text { Number of projects developed with } \\
\text { other RIs, universities, etc. } \\
\text { New collaborations... }\end{array}$ \\
\hline \multirow[t]{3}{*}{$\begin{array}{l}\text { Be an enabling facility to } \\
\text { support innovation }\end{array}$} & $\begin{array}{l}\text { T18-Patents with a } \\
\text { commercial use }\end{array}$ & $\begin{array}{l}\text { Number of patents and licensing } \\
\text { (financial value of these patents) }\end{array}$ \\
\hline & $\begin{array}{l}\text { T20-Innovations co- } \\
\text { developed with } \\
\text { industry }\end{array}$ & $\begin{array}{l}\text { Number of innovations/patents co- } \\
\text { developed with industry }\end{array}$ \\
\hline & $\begin{array}{l}\text { T24-Collaborative } \\
\text { projects with } \\
\text { industrial partners } \\
\end{array}$ & $\begin{array}{l}\text { Number of industrial users, number } \\
\text { of collaborative projects in which } \\
\text { industry is directly involved }\end{array}$ \\
\hline \multirow[t]{4}{*}{$\begin{array}{l}\text { Become integrated in a regional } \\
\text { cluster/in regional strategies / } \\
\text { Be a hub to facilitate regional } \\
\text { collaborations }{ }^{5}\end{array}$} & $\begin{array}{l}\text { E27-Number of Full } \\
\text { Time Equivalent } \\
\text { within the RI }\end{array}$ & $\begin{array}{l}\text { Number of FTE (per year), Gender } \\
\text { distribution, Nationality distribution. } \\
\text { If relevant, number of part-time } \\
\text { employees }\end{array}$ \\
\hline & $\begin{array}{l}\text { S11-Papers co- } \\
\text { authored with } \\
\text { regional universities }\end{array}$ & $\begin{array}{l}\text { Number of articles co-authored by the } \\
\text { RI and one or more regional } \\
\text { universities }\end{array}$ \\
\hline & $\begin{array}{l}\text { T25-Regional firms } \\
\text { using the RI } \\
\text { facilities }\end{array}$ & $\begin{array}{l}\text { Number of regional firms using the } \\
\text { RI (can be categorized by } \\
\text { size/turnover) }\end{array}$ \\
\hline & $\begin{array}{l}\text { E35-Number of } \\
\text { local/regional } \\
\text { suppliers }\end{array}$ & $\begin{array}{l}\text { Number of suppliers (local/regional), } \\
\text { may also add turnover data }\end{array}$ \\
\hline
\end{tabular}




\begin{tabular}{|c|c|c|}
\hline \multirow[t]{4}{*}{$\begin{array}{l}\text { Promote education outreach } \\
\text { and knowledge transfer }\end{array}$} & $\begin{array}{l}\text { O51-Public } \\
\text { visibility of the RI }\end{array}$ & $\begin{array}{l}\text { Number of occurrence of the RI in } \\
\text { media (can use online news } \\
\text { aggregations services such as } \\
\text { Factiva), including analyses at } \\
\text { different geographic scales }\end{array}$ \\
\hline & $\begin{array}{l}\text { O53-Knowledge } \\
\text { sharing }\end{array}$ & $\begin{array}{l}\text { Number of scientific conferences, } \\
\text { seminars, webinars etc. organised by } \\
\text { the RI } \\
\text { Total number of people trained } \\
\text { (academic and industry) }\end{array}$ \\
\hline & $\begin{array}{l}\text { H43-Students } \\
\text { trained and } \\
\text { distribution }\end{array}$ & $\begin{array}{l}\text { Number of students trained and their } \\
\text { origin (local/national/international) }\end{array}$ \\
\hline & $\begin{array}{l}\text { H44-Educational } \\
\text { and outreach } \\
\text { activities }\end{array}$ & $\begin{array}{l}\text { Number of educational and outreach } \\
\text { activities, number of participants }\end{array}$ \\
\hline \multirow[t]{2}{*}{$\begin{array}{l}\text { Provide scientific support to } \\
\text { public policies }\end{array}$} & $\begin{array}{l}\text { O46-Production of } \\
\text { expert advice in } \\
\text { support of public } \\
\text { policies }\end{array}$ & $\begin{array}{lcr}\text { Number of } & \text { contracts } & \text { with } \\
\text { public/policy } & \text { services } & \text { for } \\
\text { consulting/production of reports } & \end{array}$ \\
\hline & $\begin{array}{l}\text { O47-Production of } \\
\text { resources in support } \\
\text { of public policies }\end{array}$ & $\begin{array}{l}\text { Number of } \\
\text { data/specimen/informatics resources } \\
\text { dedicated to support public policies }\end{array}$ \\
\hline \multirow[t]{3}{*}{$\begin{array}{l}\text { Provide high quality scientific } \\
\text { data and associated services }\end{array}$} & $\begin{array}{l}\text { O49-Production of } \\
\text { experimental and } \\
\text { observational data in } \\
\text { support of public } \\
\text { policies }\end{array}$ & $\begin{array}{l}\text { References of experimental } \\
\text { observational data produced / used in } \\
\text { support of public policies (in } \\
\text { regulations, policy reports...) }\end{array}$ \\
\hline & T27-Data sharing & $\begin{array}{l}\text { Number of data requests (commercial } \\
\text { and academic entities) } \\
\text { Number of data accesses (commercial } \\
\text { and academic entities) }\end{array}$ \\
\hline & $\begin{array}{l}\text { T28-Commercial } \\
\text { data use and data } \\
\text { services }\end{array}$ & $\begin{array}{l}\text { Value of data (direct or indirect } \\
\text { commercial value) } \\
\text { Data package sold and turnover }\end{array}$ \\
\hline \multirow[t]{3}{*}{$\begin{array}{l}\text { Assume social responsibility } \\
\text { towards society }\end{array}$} & $\begin{array}{l}\text { O55-Energy } \\
\text { consumption } \\
\text { O56-Waste } \\
\text { management }\end{array}$ & $\begin{array}{l}\text { Statistics on energy consumption, } \\
\text { water and waste management and } \\
\text { recycling } \\
\text { Energy or environmental certification } \\
\text { Stories on how the RI minimizes its } \\
\text { environmental impact/footprint } \\
\text { (initiatives, practices...) }\end{array}$ \\
\hline & $\begin{array}{l}\text { O57-Gender balance } \\
\text { and diversity }\end{array}$ & $\begin{array}{l}\text { Gender distribution of employees, } \\
\text { users and trainees } \\
\text { Diversity of the staff and users }\end{array}$ \\
\hline & $\begin{array}{l}\text { O58-Corporate } \\
\text { social responsibility }\end{array}$ & $\begin{array}{l}\text { Ethical rules } \\
\text { Supply chain } \\
\text { Good working conditions }\end{array}$ \\
\hline
\end{tabular}

To facilitate the use of the proposed CIIs, Table 3 presents these CIIs in a matrix sorted by both strategic objectives and impact categories. 
20 ASSESSING THE SCIENTIFIC AND SOCIO-ECONOMIC IMPACT OF RESEARCH INFRASTRUCTURES

Table 3. Matrix presenting Core Impact Indicators sorted by Strategic objectives and Impact

\begin{tabular}{|c|c|c|c|c|c|}
\hline $\begin{array}{l}\text { Impact Category: } \\
\text { Strategic Objective: }\end{array}$ & Scientific Impact & Technological Impact & Training and Education Impact & Economic Impact & Social and societal Impact \\
\hline $\begin{array}{l}\text { 1.Be a national or world } \\
\text { scientific leading RI and an } \\
\text { enabling facility to support } \\
\text { science }\end{array}$ & $\begin{array}{l}\text { S2-Number of citations } \\
\text { S3-Number of publications in high-impact } \\
\text { factor journals } \\
\text { S4-Number of projects granted } \\
\text { S6-Number of scientific users } \\
\text { S9-Collaboration excellence (scientific) } \\
\text { S10-Structuring effects of the RI on the } \\
\text { scientific community }\end{array}$ & & & & \\
\hline $\begin{array}{l}\text { 2. Be and enabling facility } \\
\text { to support innovation }\end{array}$ & & $\begin{array}{l}\text { T18-Patents with commercial } \\
\text { use } \\
\text { T20-Innovations co- } \\
\text { developed with industry } \\
\text { T24-Collaborative projects } \\
\text { with industrial partners }\end{array}$ & & & \\
\hline $\begin{array}{l}\text { 3. Become integrated in a } \\
\text { regional cluster/in regional } \\
\text { strategies/be the hub to } \\
\text { facilitate regional } \\
\text { collaborations }\end{array}$ & $\begin{array}{l}\text { S11-Papers co-authored with regional } \\
\text { universities }\end{array}$ & $\begin{array}{l}\text { T25-Regional firms using the } \\
\text { RI facilities }\end{array}$ & & $\begin{array}{l}\text { E34-Number of Full Time } \\
\text { Equivalent within the RI } \\
\text { E35- Number of } \\
\text { local/regional suppliers }\end{array}$ & \\
\hline $\begin{array}{l}\text { 4. Promote education, } \\
\text { outreach and knowledge } \\
\text { dissemination }\end{array}$ & & & $\begin{array}{l}\text { H43-Students trained and distribution } \\
\text { H45-Educational and outreach activities }\end{array}$ & & $\begin{array}{l}\text { O51-Public visibility of the RI } \\
\text { O53-Knowledge sharing }\end{array}$ \\
\hline
\end{tabular}




\begin{tabular}{|c|c|c|}
\hline $\begin{array}{l}\text { 5. Provide scientific } \\
\text { support to public policies }\end{array}$ & & $\begin{array}{l}\text { O46-Production of expert advice in } \\
\text { support of public policies } \\
\text { O47-Production of resources in } \\
\text { support of public policies }\end{array}$ \\
\hline $\begin{array}{l}\text { 6. Provide high quality } \\
\text { scientific data and } \\
\text { associated services }\end{array}$ & $\begin{array}{l}\text { T27-Data sharing } \\
\text { T28-Data commercial use } \\
\text { and data services }\end{array}$ & $\begin{array}{l}\text { O49-Production of experimental } \\
\text { and observational data in support of } \\
\text { public policies }\end{array}$ \\
\hline 7. Social responsibility & & $\begin{array}{l}\text { O55-Energy consumption } \\
\text { O56-Waste management } \\
\text { O57-Gender balance and diversity } \\
\text { O58-Corporate social responsibility }\end{array}$ \\
\hline
\end{tabular}

Letter signification: S: Scientific impact; T: Technological impact; E: Economic impact; H: Training and education impact; O: Social and societal impact. This same list of Core Impact Indicators is presented in Appendix 3, taking into account their relevance with respect to RI types and lifecycle phase. 


\subsection{Comprehensive List of Indicators}

While CIIs could be used by most of the RIs we analysed and constitute a good baseline for monitoring the impact of RIs on a regular basis, they do not necessarily reflect the specificities of each RI. The more comprehensive list of 58 indicators presented in Table 4 includes all indicators that were identified during the surveys as being in use, or of interest, by more than one RI.

This table allows managers and stakeholders to have a larger choice of indicators to monitor a strategic objective. It includes more detailed information for each indicator (what each indicator means in term of impact, the data required for the indicator to be operative and references to relevant publications for more details on the use of those indicators). This list is also available in Appendix 4 with the indicators classified according to strategic objectives.

In some cases the production of robust and meaningful quantitative measures may be difficult. In these cases, qualitative studies or "narratives" may provide a suitable alternative. Although in these cases progress may be harder to track, they can nevertheless provide useful information to assess the impact of an RI.

Table 4. Comprehensive list of indicators

\begin{tabular}{|c|c|c|c|}
\hline & Indicators & Detail & Data needed \\
\hline S1 & Number of publications & $\begin{array}{l}\text { Peer-reviewed articles is an indicator of } \\
\text { scientific activity in most scientific } \\
\text { fields, demonstrates the impact of the } \\
\text { RI on science }\end{array}$ & $\begin{array}{l}\text { Total number of publications of the RI during a } \\
\text { given period } \\
\text { Online on Scopus, WoS and / or other relevant } \\
\text { databases. Including only papers with RI address } \\
\text { (Griniece et al., 2015; Dasgupta and David, 1994) }\end{array}$ \\
\hline S2 & Number of citations & Quality of RI publications and number & $\begin{array}{l}\text { Total number of citations received by publications } \\
\text { which are including authors from RI and RI users. } \\
\text { (Griniece et al., 2015; Dasgupta and David, 1994) }\end{array}$ \\
\hline S3 & $\begin{array}{l}\text { Number of publications } \\
\text { in High-Impact factor } \\
\text { journals }\end{array}$ & $\begin{array}{l}\text { Publication in world-class journals with } \\
\text { high impact }\end{array}$ & $\begin{array}{l}\text { Number of publications in database from RI users } \\
\text { published within Q1 journals. } \\
\text { (Hallonsten and Christensson, 2017; Florio et al., } \\
\text { 2017) }\end{array}$ \\
\hline S4 & $\begin{array}{l}\text { Number of projects } \\
\text { granted }\end{array}$ & $\begin{array}{l}\text { Demonstrates the RI capacity to attract } \\
\text { funding and excellence of its projects }\end{array}$ & $\begin{array}{l}\text { Total number of projects funded by external } \\
\text { sources including industry funds. } \\
\text { Projects = scientific collaboration, industrial } \\
\text { collaboration, technical development etc. } \\
\text { (Brottier, 2016; Rosenberg, 1992) }\end{array}$ \\
\hline S5 & $\mathrm{RI}$ attractiveness & $\begin{array}{l}\text { Demand for use such as: } \\
\% \text { subscribed } \\
\% \text { oversubscribed }\end{array}$ & $\begin{array}{l}\text { Number of applications for the use of the Rl's } \\
\text { facility } \\
\text { Number of non-scientific users } \\
\text { (Hallonsten and Christensson, 2017) }\end{array}$ \\
\hline S6 & $\begin{array}{l}\text { Number of scientific } \\
\text { users }\end{array}$ & $\begin{array}{l}\text { Demonstrates the RI attractiveness in } \\
\text { different disciplines }\end{array}$ & $\begin{array}{l}\text { Number of users } \\
\text { Discipline distribution } \\
\text { Top scientific users } \\
\text { Nationality distribution } \\
\text { (Griniece et al., 2015; Florio et al., 2017) }\end{array}$ \\
\hline S7 & User satisfaction & $\begin{array}{l}\text { Based on survey results; a survey can } \\
\text { be run to measure user satisfaction on } \\
\text { project selection, support and other } \\
\text { items, to evaluate how the RI answers } \\
\text { its user needs }\end{array}$ & $\begin{array}{l}\text { Satisfaction of Rl users regarding project } \\
\text { selection, access, support, availability of } \\
\text { instruments... } \\
\text { (Griniece et al., 2015) }\end{array}$ \\
\hline
\end{tabular}




\begin{tabular}{|c|c|c|c|}
\hline S8 & User project excellence & $\begin{array}{l}\text { Demonstrates the RI capacity } \\
\text { to attract and select excellent } \\
\text { projects }\end{array}$ & $\begin{array}{l}\text { Ratio of funded projects vs the total } \\
\text { number of projects applications } \\
\text { (Kolarz, 2017) }\end{array}$ \\
\hline S9 & Collaboration excellence (scientific) & $\begin{array}{l}\text { The number of scientific } \\
\text { collaborations is a way to } \\
\text { measure how a RI enables } \\
\text { cooperation in its scientific } \\
\text { domain and impacts science }\end{array}$ & $\begin{array}{l}\text { Total number of applications for using } \\
\text { the RI and origin } \\
\text { Total number of applications from } \\
\text { world leading teams (World leading } \\
\text { teams publish regularly in Q1 } \\
\text { journals) } \\
\text { Joint grants } \\
\text { (Kolarz, 2017) }\end{array}$ \\
\hline S10 & $\begin{array}{l}\text { Structuring effects of the RI on the } \\
\text { scientific community }\end{array}$ & $\begin{array}{l}\text { To measure the visibility, } \\
\text { attractiveness and } \\
\text { community building of the RI }\end{array}$ & $\begin{array}{l}\text { Number of projects developed with } \\
\text { other RIs, universities, etc. } \\
\text { New collaborations... }\end{array}$ \\
\hline S11 & $\begin{array}{l}\text { Papers co-authored with regional } \\
\text { universities }\end{array}$ & $\begin{array}{l}\text { Measure scientific } \\
\text { productivity and the capacity } \\
\text { to enable cooperation with } \\
\text { regional scientific actors }\end{array}$ & $\begin{array}{l}\text { Number of articles co-authored } \\
\text { between the RI and one or more } \\
\text { regional universities or research } \\
\text { organisations. } \\
\text { Information from Scopus, World of } \\
\text { Science or other relevant databases } \\
\text { Including only papers with RI address } \\
\text { (ESS, 2018) }\end{array}$ \\
\hline S12 & Use and production of open data & $\begin{array}{l}\text { How the RI contributes to the } \\
\text { development of open science }\end{array}$ & $\begin{array}{l}\text { Number of access, upload and } \\
\text { download of open data } \\
\text { Use and users of the open data } 6 \\
\text { produced by the RI (users, publics, } \\
\text { external researchers, and internal } \\
\text { researchers) } \\
\text { (ESS, 2018) }\end{array}$ \\
\hline S13 & Data openness & $\begin{array}{l}\text { Attractiveness and quality of } \\
\text { access to RI resources can } \\
\text { create/reinforce scientific } \\
\text { communities and improve } \\
\text { their quality }\end{array}$ & $\begin{array}{l}\text { Number of applications to use Rl's } \\
\text { existing data } \\
\text { Number of access granted } \\
\text { (Jimenez, 2017) }\end{array}$ \\
\hline S14 & Digital resource openness & $\begin{array}{l}\text { Attractiveness and quality of } \\
\text { access to RI digital resources } \\
\text { create / reinforce scientific } \\
\text { communities }\end{array}$ & $\begin{array}{l}\text { Number of access to digital resources } \\
\text { granted } \\
\text { Number of digital resources access } \\
\text { requests } \\
\text { (Jimenez, 2017) }\end{array}$ \\
\hline T15 & National grants & $\begin{array}{l}\text { National grants received } \\
\text { demonstrate the Rl } \\
\text { excellence }\end{array}$ & $\begin{array}{l}\text { Number of grants/total amount from } \\
\text { the host country for research and } \\
\text { development projects } \\
\text { (Rosenberg, 1992) }\end{array}$ \\
\hline T16 & Collaboration with national industry & $\begin{array}{l}\text { Measures the attractiveness } \\
\text { to industry and innovation } \\
\text { potential }\end{array}$ & $\begin{array}{l}\text { Number of projects in collaboration } \\
\text { with national firms } \\
\text { Story of successful collaboration } \\
\text { (Rochow et al., 2011; Katz, 1994) }\end{array}$ \\
\hline T17 & Patents & $\begin{array}{l}\text { The number of patents } \\
\text { developed by the RI } \\
\text { demonstrate its impact on } \\
\text { innovation }\end{array}$ & $\begin{array}{l}\text { Number of patents granted } \\
\text { (Autio, Bianchi-Streit and Hameri, } \\
\text { 2003) }\end{array}$ \\
\hline T18 & Patents with a commercial use & $\begin{array}{l}\text { Commercial use } \\
\text { demonstrates the usefulness } \\
\text { of the patents developed by } \\
\text { the RI }\end{array}$ & $\begin{array}{l}\text { Number of patents and } \\
\text { commercial/financial value of these } \\
\text { patents } \\
\text { (STFC, 2014) }\end{array}$ \\
\hline T19 & Co-patenting with companies & $\begin{array}{l}\text { The number of patents co- } \\
\text { developed by the RI } \\
\text { demonstrates its impact on } \\
\text { innovation and development } \\
\text { of cooperation networks }\end{array}$ & $\begin{array}{l}\text { Number of co-patents with companies } \\
\text { (Pilar, 2012; Jaffe, 1989) }\end{array}$ \\
\hline T20 & Innovations co-developed with industry & $\begin{array}{lcc}\text { Emergence } & \text { of } & \text { new } \\
\text { cooperation } & \text { networks } & \text { with }\end{array}$ & $\begin{array}{l}\text { Number of innovations co-developed } \\
\text { with industry }\end{array}$ \\
\hline
\end{tabular}




\begin{tabular}{|c|c|c|c|}
\hline & & $\begin{array}{l}\text { industry is a major } \\
\text { mechanism through which } \\
\text { knowledge circulates and } \\
\text { impacts innovation }\end{array}$ & (Pilar, 2012; Marsili, 2001) \\
\hline T21 & $\begin{array}{l}\text { Joint technology development projects } \\
\text { between RI and industry }\end{array}$ & $\begin{array}{l}\text { These projects are a major } \\
\text { mechanism through which } \\
\text { knowledge circulates and } \\
\text { impacts innovation }\end{array}$ & $\begin{array}{l}\text { Number of joint technology } \\
\text { development projects between RI and } \\
\text { industry } \\
\text { (ESS, 2018; Marsili, 2001) }\end{array}$ \\
\hline T22 & Students working for industry & $\begin{array}{l}\text { Development of high skill } \\
\text { students for industry }\end{array}$ & $\begin{array}{l}\text { Number of students (PhD, master) } \\
\text { supported by the private sector and } \\
\text { using the RI } \\
\text { (Pilar, 2012; Senker, 1995) }\end{array}$ \\
\hline T23 & Projects funded by companies & $\begin{array}{l}\text { A proxy to understand the RIs } \\
\text { attractiveness and its } \\
\text { potential for innovation }\end{array}$ & $\begin{array}{l}\text { Number of funded projects by } \\
\text { companies } \\
\text { (Saler and Martin, 2001) }\end{array}$ \\
\hline T24 & $\begin{array}{l}\text { Collaborative projects with industrial } \\
\text { partners }\end{array}$ & $\begin{array}{l}\text { New collaborative projects } \\
\text { carried out with industry are a } \\
\text { major mechanism through } \\
\text { which knowledge circulates } \\
\text { and impacts innovation }\end{array}$ & $\begin{array}{l}\text { Number of collaborative projects in } \\
\text { which industry is directly involved } \\
\text { (Rochow et al., 2011; Marsili, 2001) }\end{array}$ \\
\hline T25 & Regional firms using the RI facilities & $\begin{array}{l}\text { Contributes to the } \\
\text { development of the regional } \\
\text { firms skills and impacts on } \\
\text { their innovation capacity }\end{array}$ & $\begin{array}{l}\text { Number of regional firms using the RI } \\
\text { (Brottier, 2016; Autio, Bianchi-Streit } \\
\text { and Hameri, 2003) }\end{array}$ \\
\hline T26 & $\begin{array}{l}\text { Collaborative projects with regional } \\
\text { industrial partners }\end{array}$ & $\begin{array}{l}\text { Contribute to the } \\
\text { development of the regional } \\
\text { firms skills and impact on } \\
\text { their innovation capacity }\end{array}$ & $\begin{array}{l}\text { Number of collaborative projects with } \\
\text { regional industrial partners } \\
\text { (ESS, 2018; Katz, 1994) }\end{array}$ \\
\hline T27 & Data sharing & $\begin{array}{l}\text { Access and use of the data } \\
\text { produced and services } \\
\text { provided by the RI }\end{array}$ & $\begin{array}{l}\text { Number of data demands } \\
\text { Number of data accesses } \\
\text { Number of data accesses by } \\
\text { commercial actors and public entities } \\
\text { (Barratt, Wang and Binney, 2016) }\end{array}$ \\
\hline T28 & Data commercial use and data services & $\begin{array}{l}\text { Commercial use of the data } \\
\text { and services provided by the } \\
\text { RI }\end{array}$ & $\begin{array}{l}\text { Financial/commercial value of data } \\
\text { Turnover of data packages sold } \\
\text { (Barratt, Wang and Binney, 2016) }\end{array}$ \\
\hline T29 & Data usage & $\begin{array}{l}\text { The usage of the resources } \\
\text { delivered by the RI illustrates } \\
\text { its various technological } \\
\text { impacts }\end{array}$ & $\begin{array}{l}\text { Overall usage via browser and other } \\
\text { methods } \\
\text { Usage in research (through citations) } \\
\text { Use of data by public entities } \\
\text { (Jimenez, 2017) }\end{array}$ \\
\hline E30 & Total expenditure in regional / local area & $\begin{array}{l}\text { All the regional/local RI } \\
\text { expenditures have an impact } \\
\text { on the economy }\end{array}$ & $\begin{array}{l}\text { Total amount of expenditures in } \\
\text { regional area, including total amount } \\
\text { of purchase from suppliers, contract } \\
\text { with suppliers and others, estimation } \\
\text { of economic impact on regional area } \\
\text { (Rochow et al., 2011; Prettner and } \\
\text { Werner, 2016) }\end{array}$ \\
\hline E31 & Public procurement and contracts & $\begin{array}{l}\text { Development of new skills, } \\
\text { technology and industrial } \\
\text { processes, innovation } \\
\text { induced through public } \\
\text { procurement }\end{array}$ & $\begin{array}{l}\text { Total amount of purchase from a } \\
\text { local/national/regional suppliers } \\
\text { Total amount of contracts with } \\
\text { local/national/regional suppliers } \\
\text { (EFDA, 2001; Florio et al., 2016) }\end{array}$ \\
\hline E32 & $\begin{array}{l}\text { Total number of visitors and users of the } \\
\text { RI }\end{array}$ & $\begin{array}{l}\text { Increased revenues for the } \\
\text { local economy (tourism } \\
\text { principally) }\end{array}$ & $\begin{array}{l}\text { Number of visitors and users (to be } \\
\text { related to average spending within } \\
\text { local area) } \\
\text { (Hallonsten and Christensson, 2017; } \\
\text { Florio, Forte and Sirtori, 2016) }\end{array}$ \\
\hline E33 & New tax payers & $\begin{array}{l}\text { Employees living in the local } \\
\text { area can increase revenues } \\
\text { for the region }\end{array}$ & $\begin{array}{l}\text { Number of employees, living in the } \\
\text { local area for } 3 \text { years at least } \\
\text { (Florio, Forte and Sirtori, 2016) }\end{array}$ \\
\hline
\end{tabular}




\begin{tabular}{|c|c|c|c|}
\hline E34 & $\begin{array}{l}\text { Number of Full Time Equivalent within the } \\
\text { RI }\end{array}$ & $\begin{array}{l}\text { Development of new skills } \\
\text { and increase of the economic } \\
\text { activity of the region } \\
\text { (multiplier) }\end{array}$ & $\begin{array}{l}\text { Number of FTE (all persons working } \\
\text { within the RI), per year } \\
\text { Diversity distribution } \\
\text { RI Alumni } \\
\text { (Griniece et al, 2015; Florio, Forte and } \\
\text { Sirtori, 2016) }\end{array}$ \\
\hline E35 & Number of local/ regional suppliers & $\begin{array}{l}\text { Increased revenues of } \\
\text { suppliers and related new } \\
\text { skills impact the economic } \\
\text { activity of the region }\end{array}$ & $\begin{array}{l}\text { Number of suppliers (regional and } \\
\text { local) } \\
\text { (Griniece et al, 2015) }\end{array}$ \\
\hline E36 & Number of employees & $\begin{array}{l}\text { Highly skilled employees can } \\
\text { provide indirect benefits for } \\
\text { the local economy }\end{array}$ & $\begin{array}{l}\text { Number of engineers } \\
\text { Number of scientists } \\
\text { Number of administrative staff } \\
\text { Other (technicians...) } \\
\text { Diversity distribution } \\
\text { Evolution of employees and their } \\
\text { distribution } \\
\text { (Hallin, 2012; Godin and Doré, 2014) }\end{array}$ \\
\hline E37 & Spin-off companies & $\begin{array}{l}\text { New jobs created in the local } \\
\text { economy, R\&D spillovers }\end{array}$ & $\begin{array}{l}\text { Number of spin-off companies (start- } \\
\text { ups created by researchers of RI) } \\
\text { (Griniece, Reid and Angelis, 2015; } \\
\text { Martin et al., 1996) }\end{array}$ \\
\hline $\mathrm{H} 38$ & Trained students satisfaction & $\begin{array}{l}\text { Based on survey results: a } \\
\text { survey can be run to measure } \\
\text { students satisfaction (on } \\
\text { training courses, support, } \\
\text { help, etc.), to assess how a RI } \\
\text { answers its students' needs }\end{array}$ & $\begin{array}{l}\text { Satisfaction of students towards the } \\
\text { training courses } \\
\text { (Jimenez, 2017) }\end{array}$ \\
\hline H39 & Use of the data for training & $\begin{array}{l}\text { To illustrate the impact of the } \\
\text { data produced by the RI on } \\
\text { teaching and training }\end{array}$ & Survey within RI and among teachers \\
\hline $\mathrm{H} 40$ & Number of graduates (regional) & $\begin{array}{l}\text { Development of new skills } \\
\text { and indirect benefits for the } \\
\text { economy }\end{array}$ & $\begin{array}{l}\text { Number of MSc and PhD students } \\
\text { from local universities using the RI } \\
\text { (PwC, 2016; Martin et al., 1996) }\end{array}$ \\
\hline $\mathrm{H} 41$ & Career of students trained within the RI & $\begin{array}{l}\text { Indicator to demonstrate the } \\
\text { effect of the RI training on } \\
\text { students, and its impact on } \\
\text { society }\end{array}$ & Survey results \\
\hline $\mathrm{H} 42$ & Grants for trainees & $\begin{array}{l}\text { Illustrates the importance of } \\
\text { the training activity of the RI }\end{array}$ & $\begin{array}{l}\text { Volume of grants awarded to trainees } \\
\text { (regional, national grants for example) } \\
\text { to use the RI (total volume) } \\
\text { (Pilar, 2012; Martin et al., 1996) }\end{array}$ \\
\hline $\mathrm{H} 43$ & Students trained and distribution & $\begin{array}{l}\text { lllustrates the } \mathrm{Rl} \\
\text { attractiveness and excellence } \\
\text { of its training }\end{array}$ & $\begin{array}{l}\text { Number of students trained within the } \\
\mathrm{RI} \text { Distribution (national and } \\
\text { international students) } \\
\text { (Jimenez, 2017; Martin et al., 1996) }\end{array}$ \\
\hline $\mathrm{H} 44$ & $\begin{array}{l}\text { Training programmes for high level } \\
\text { students }\end{array}$ & $\begin{array}{l}\text { Illustrates the RI role in the } \\
\text { training of future scientists }\end{array}$ & $\begin{array}{l}\text { Number of masters and PhD training } \\
\text { programs. } \\
\text { (Arundel, Van de Paal and Soete, } \\
\text { 1995) }\end{array}$ \\
\hline
\end{tabular}




\begin{tabular}{|c|c|c|c|}
\hline $\mathrm{H} 45$ & Educational and outreach activities & $\begin{array}{l}\text { The educational and } \\
\text { outreach activities have an } \\
\text { indirect impact on } \\
\text { participants } \\
\text { sknowledge and } \\
\text { skills }\end{array}$ & $\begin{array}{l}\text { Total number of participants } \\
\text { Total number of educational and } \\
\text { outreach activities (open days and } \\
\text { other events), internal human } \\
\text { resources dedicated } \\
\text { (OECD, 2014; Arundel, Van de Paal } \\
\text { and Soete, 1995) }\end{array}$ \\
\hline 046 & $\begin{array}{l}\text { Production of expert advice in support of } \\
\text { public policies }\end{array}$ & $\begin{array}{l}\text { Consulting activity for public } \\
\text { services shows the potential } \\
\text { Rls' influence on public } \\
\text { policies (and further impact } \\
\text { for citizens in the longer term) }\end{array}$ & $\begin{array}{l}\text { Number of contracts with public } \\
\text { services for consulting or reports } \\
\text { related to support of public policies } \\
\text { (Barratt, Wang and Binney, 2016; } \\
\text { Rizzuto, 2012) }\end{array}$ \\
\hline 047 & $\begin{array}{l}\text { Production of resources used in support of } \\
\text { public policies }\end{array}$ & $\begin{array}{l}\text { Resources dedicated to } \\
\text { support public policies can } \\
\text { impact citizens in the long } \\
\text { term }\end{array}$ & $\begin{array}{l}\text { Volume of databases / biobanks / } \\
\text { informatics resources used to support } \\
\text { public policies } \\
\text { (TRIUMF, 2013; Rizzuto, 2012) }\end{array}$ \\
\hline O48 & $\begin{array}{l}\text { Contribution of the RI researchers to } \\
\text { public policies }\end{array}$ & $\begin{array}{l}\text { Indicators demonstrating the } \\
\text { researcher contributions } \\
\text { (conferences, meetings, } \\
\text { reports...) to public policies }\end{array}$ & $\begin{array}{l}\text { Number of meetings with policy } \\
\text { makers } \\
\text { Number of others contributions } \\
\text { (expert reports, conferences, articles } \\
\text { in regulatory or legal texts) } \\
\text { (Barratt, Wang and Binney, 2016) }\end{array}$ \\
\hline 049 & $\begin{array}{l}\text { Production of experimental and } \\
\text { observational data in support of public } \\
\text { policies }\end{array}$ & $\begin{array}{l}\text { These data dedicated to } \\
\text { support public policies can } \\
\text { impact citizens in the long } \\
\text { term }\end{array}$ & $\begin{array}{l}\text { Volume of experimental } \\
\text { observational data produced/used in } \\
\text { support of public policies } \\
\text { (Barratt, Wang and Binney, 2016) }\end{array}$ \\
\hline 050 & Public awareness & $\begin{array}{l}\text { Public and users reached by } \\
\text { the RI website }\end{array}$ & $\begin{array}{l}\text { Number of visits/consultations on the } \\
\text { RI website } \\
\text { (The Tori Group, 2013) }\end{array}$ \\
\hline 051 & Public visibility of the RI & $\begin{array}{l}\text { Measuring the RI occurrence } \\
\text { in online media is an efficient } \\
\text { way to see its popularity }\end{array}$ & $\begin{array}{l}\text { Number of appearances of the RI on } \\
\text { Factiva (all subjects) in online media } \\
\text { (The Tori Group, 2013; Rizzuto, 2012) }\end{array}$ \\
\hline 052 & Popularity of the RI (public and users) & $\begin{array}{l}\text { The number of followers on } \\
\text { social media is a measure of } \\
\text { the public interest in the RI }\end{array}$ & $\begin{array}{l}\text { Number of followers on selected } \\
\text { social medias } \\
\text { (Linkedln, Facebook, Youtube, } \\
\text { Twitter, Baidu, etc.) } \\
\text { (The Tori Group, 2013; Rizzuto, 2012) }\end{array}$ \\
\hline 053 & Knowledge sharing & $\begin{array}{l}\text { Scientific events organized } \\
\text { and number of people trained } \\
\text { to demonstrate the impact on } \\
\text { human resources } \\
\text { (development of skills and } \\
\text { knowledge) }\end{array}$ & $\begin{array}{l}\text { Number of scientific and technological } \\
\text { conferences, seminars, workshops, } \\
\text { webinars etc. organised by the RI } \\
\text { Total number of people trained } \\
\text { (academic and industry) } \\
\text { (Arundel, Van de Paal and Soete, } \\
\text { 1995) }\end{array}$ \\
\hline 054 & Openness to public & $\begin{array}{l}\text { Events successfully } \\
\text { organized by the RI for the } \\
\text { public to produce / improve its } \\
\text { image }\end{array}$ & $\begin{array}{l}\text { Number of events organized for the } \\
\text { public } \\
\text { Number of visitors in those events } \\
\text { (Griniece, Reid and Angelis, 2015; } \\
\text { Arundel, Van de Paal and Soete, } \\
\text { 1995) }\end{array}$ \\
\hline 055 & Energy consumption & $\begin{array}{l}\text { What is done by the RI to } \\
\text { save energy during } \\
\text { construction and its } \\
\text { functioning: effect on } \\
\text { environment and } \mathrm{Rl} \\
\text { exemplarity }\end{array}$ & $\begin{array}{l}\text { Energy usage } \\
\text { Energy labels } \\
\text { Narrative on energy saving during the } \\
\text { different RI lifecycle phases } \\
\text { (Rochow, R. et al., 2018; Godin and } \\
\text { Doré, 2014) }\end{array}$ \\
\hline
\end{tabular}




\begin{tabular}{|c|l|l|l|}
\hline 056 & Waste management & $\begin{array}{l}\text { How the RI manages the } \\
\text { waste: effect on environment } \\
\text { Rl exemplarity }\end{array}$ & $\begin{array}{l}\text { Waste production, water usage, } \\
\text { recycling data, label, } \\
\text { (Rochow, R. et al., 2018; Godin and } \\
\text { Doré, 2014) }\end{array}$ \\
\hline 057 & Gender balance and diversity & $\begin{array}{l}\text { Demonstrates the effort } \\
\text { made by the RI for equity (RI } \\
\text { exemplarity) }\end{array}$ & $\begin{array}{l}\text { Gender distribution of employees, } \\
\text { users and trainees. } \\
\text { Diversity of the staff, users... } \\
\text { (Björling, 2018) }\end{array}$ \\
\hline 058 & Corporate social responsibility & $\begin{array}{l}\text { Showing the RI as an } \\
\text { example of social } \\
\text { responsibility }\end{array}$ & $\begin{array}{l}\text { Internal survey } \\
\text { Ethical guidelines } \\
\text { Responsible suppliers (label) } \\
\text { Good working conditions }\end{array}$ \\
\hline
\end{tabular}

It should be noted that the majority of these indicators, which are based on current practices, are very traditional. In some cases they may not be fully consistent with more recent policies that are being promoted by some RI stakeholders. This is notable in relation to Open Science, where there is a growing movement to promote open access publishing, which is not the model adopted by the highest impact journals (S4). There is also considerable unrest in the scientific and policy community about the use of citation indices as measures of impact (S2). Similarly, charging for data access (T28) may be inconsistent with policies to promote enhanced access to research data. However, in the absence of accepted indicators that address these concerns, judicious selection from the proposed set is a good starting point for impact assessment. All indicators have caveats and new indicators are certainly required and in some areas, such as data access, there can be an important role for RIs in helping to develop and test these.

\subsection{Using the framework}

This section describes how to select indicators, how to collect data efficiently and how to analyse/use the results afterwards

\section{Preparing for impact assessment: selecting indicators}

It is recommended that RIs, together with their stakeholders, first identify the various types of impact they wish to assess, related to their strategic objectives. They can then identify Core Impact Indicators i.e. generic indicators which will provide an overall picture of the socio-economic impact of the RI on a regular basis and are important to inform a dialogue with stakeholders. These CIIs can be relatively broad at first and become more precise over time in the light of experience. They can than supplement/refine these CIIs with a set of standard indicators which will cover all the detailed aspects of impact and can be adjusted over time alongside the evolution of the RI.

There are three basic rules to follow in order to select indicators:

- Indicators should be linked with strategic objectives.

- They have to provide information relevant to operational issues.

- They should be time-bounded, so that they can be used to assess evolution over set periods. They should also be stable over time to ensure consistency. Nevertheless, it is still possible to add (and subtract) indicators for different phases of the RI's lifecycle. 
As indicated in chapter 5.4, indicators are not perfect proxies for impact assessment. These limitations should be well understood when selecting indicators and explanations of those limits should be provided to interested stakeholders. Furthermore, indicators cannot be interpreted in absolute numbers and it is the evolution of their measurement over time that is most relevant.

The earlier the indicators are selected and agreed upon in the life of an RI, then the sooner the data can be collected. It is easier to collect data prospectively than to search for it retrospectively. In addition, it is also important to think about the RI's lifecycle: indicators and their relevance will be different for each stage. Many impact indicators can be more useful in operational phase as it is (in general) the longest phase of the life cycle and when the RI produces output that can lead to measurable impact. Impacts may nevertheless be significant during the construction phase depending on the nature of the RI,

Finally, in order to have clear, useful and relevant impact assessment, indicators should be selected by people that know the infrastructure well: its history, stakes, strategic objectives and challenges for the future.

\section{Selection of indicators: The ESS case}

The European Spallation Source (ESS) is a new European RI that started its construction in September 2014. ESS has a strong interest in impact assessment and launched its first assessment for the year 2016. The starting point is that the ESS performances cannot be assessed in a traditional way - with an exclusive focus on scientific performance or economic impact. ESS designed its indicators so that each can inform on the achievement towards the RI's strategic objectives.

With the help of an external team, ESS benchmarked other infrastructure's practices in terms of impact assessment and prepared a detailed list of indicators relevant to the construction phase and additional ones for the operational phase to come. These indicators were discussed in meetings between external teams, division managers and stakeholders, in order to fully meet the ESS needs.

The selected indicators - which are termed "metrics" instead of indicators, as "indicators" were considered as too heavily connoted as a management tool - are linked to stakeholders visions and objectives and tailored for the infrastructure's needs. Metrics are important for ESS to:

- create and collect data that are considered as useful for various uses

- better manage teams

- show how ESS fulfills its strategic objectives through the years

- communicate to stakeholders and to facilitate future funding procedures.

These metrics have been selected for their relevance and are based on data's availability.

A particularity is that each indicator measuring publications and citations is separated between technique / method, environment and neutron use, to highlight the relevance and uniqueness of ESS instruments. ESS puts a particular accent on security and reliability of the facilities and instruments (15 instruments will be running within the facility when in operational phase, starting in 2019), and on the environmental impacts of the infrastructure (important issue for local and regional authorities). But the RI also follows elements such as the cost of delays, the impact of in-kind contributions, its expenditures in local area, etc. The initial focus on short and medium-term indicators - e.g. grants, citations, collaborations, expenditures, etc. Long-term effect indicators will be assessed later on and are being considered (e.g. knowledge transfer, success rate on proposals to use instruments, potential of the infrastructure for European grand challenges, user satisfaction, etc.).

To support these quantitative indicators, ESS is working on narratives, for example to show the effects of collaborations between ESS and industries. 


\section{Data collection}

The Reference Framework for assessing the scientific and socio-economic impact of Research Infrastructures aims at minimising the work to define, collect and analyse data. It also aims at minimising the ex-post collection of data.

First of all, it is recommended to use existing databases, whenever possible. There are two advantages to using existing databases: i) it reduces the workload; ii) it can increase the reliability of data as they are usually collected in the same way (although this is not always true and should be verified).

To reduce ex-post data collection, we recommend to organise systematic data collection from the early stages and to focus on data that are easy to collect. To motivate employees to collect data, it is necessary: i) to explain clearly the role and objectives of the envisaged impact assessment(s); ii) to explain how data will be analysed; iii) to give feed-back on any impact assessments. The commitment of RI managers is key to facilitate data collection.

Internal administrative sources remain the primary providers of data but third party (external) data sources may also be necessary also to evaluate the impact of a RI. For example, data for economic impacts will be gathered from internal sources (i.e. suppliers' contracts and number, etc.) and completed by external sources (revenues of these suppliers, etc.).

When data is not readily available, inputs can be collected through surveys and then analysed. For example, surveys can be run periodically with different audiences to assess satisfaction, achievements, collaborations, expectations. The periodicity of a survey can be adapted to the expected rate of change of factors that are being assessed.

To sum up, any proposal to collect data for impact assessment requires a discussion on:

- the objectives of the assessment(s) (what will we do with the results?)

- the sources of data, internal and external (what data and where will we get it?)

- the choices and proposed methods of collection (how?)

- the likely reliability of the data (including survey data population representativeness).

\section{Examples of data collection processes}

\section{CIRRMT}

The Centre for Interdisciplinary Research in Music Media and Technology (CIRRMT) is a multi-disciplinary RI hosted by McGill University in Montreal (Canada).

Data on impact indicators are collected for reporting at two time points:

- For the yearly reports to its board, a brief overview of the scientific, artistic, and technological outcomes is produced, which is based on voluntary information provided by individual researchers and stakeholders.

- Every three years, CIRMMT produces an entire report of scientific, artistic and technological output for the funding agencies (for operational funds). This is a tedious process where each member submits their annual reports and CIRRMT management collate all the information and interpret the data. 


\section{$B B M R I$}

The Biobanking and BioMolecular Resources Research Infrastructure (BBMRI) is a distributed RI created under the European Research Infrastructure Consortium (ERIC) legal statute. It provides access to biobanks and biomolecular resources coordinated by the National Nodes for health research.

BBMRI started to collect data in 2017 for impact indicators at its central node level (situated in Graz, Austria) in parallel with the development of its KPIs. It will start also collecting data from its national nodes from 2019 to have a more global overview of its impact. Early assessments focused on classical quantitative assessments more suitable for research projects (e.g. number of publications, number of $\mathrm{PhD}$ students, patents...) rather than for BBMRI which is an RI focusing on providing services and which is often providing guidance and expertise rather than access to a single site tool or centre. Hence new data are now being collected.

Data have proven to be difficult to collect, particularly since BBMRI is a distributed RI and impact is often linked to indirect use of data and resources and not always referenced. Data collection is not yet automated and still largely relies on manual feedback from national nodes. They are collected on a yearly basis, although a quarterly periodicity is considered for some data sets. This is now an integral part of the RI management process but is recognised as being a challenge and support is being requested from stakeholders.

\section{IMEC}

The Interuniversity Microelectronics Centre (IMEC) is a world-leading R\&D and innovation hub in nano-electronics and digital technologies. IMEC was established in 1984 in Leuven (Belgium) by the Flemish Regional Authority. Current funding (operation) comes mainly (80\%) from contracts with private companies (incl. most of the top ten ICT companies in the world) and funded projects; $20 \%$ is supported by the Flemish Authority.

Data on impact indicators are regularly collected (a process coordinated by the IMEC's evaluation unit) to feed two types of evaluation:

- Impact studies are carried out by an external consultant on behalf of IMEC every 2 years.

- A strategic ex-post and ex-ante evaluation study is produced every 5 years by external consultants at the request of the Flemish Government. The ex-post report is based on IMEC's self-assessment reports (including the results of the two-yearly impact studies), bibliometric studies carried out by a specialised university centre, interviews, and benchmarking with similar RIs abroad. Recommendations are also provided by a panel of international experts.

Moreover IMEC provides yearly the results on nine KPIs to the Governing Board and the Flemish Government. Most of these KPIs are similar to (core) impact indicators identified in the OECD Reference Framework.

\section{How to use indicator data}

Indicators mirror the activities of an RI. They provide information about the level of achievement of strategic objectives and are informing interested parties about the impact of different activities. They can be used to plan activities or to model the effects of different decisions. Information on RI impact allows stakeholders and managers:

- To identify emerging problems and help focus their attention on what is not working.

- To validate the coupling between their vision, strategic objectives and the day-today decisions. 
Some of the indicators proposed can be integrated within management and reporting tools used by the RI (such as KPIs and scoreboards) although this is not mandatory.

Data collection and data analysis are two important but distinct parts of an assessment exercise. The analysis of indicators can be routine and standardised - for annual reporting - or on demand - for a specific purpose. The aim is to limit as much as possible ad hoc data collection and to include within routine annual reporting information about impact.

Results relative to each indicator can be compared with these targets (for the first year or period) or to previous results to assess the impact of the RI over the years.

\section{Using of indicators: the IMEC example}

The Interuniversity Microelectronics Centre (IMEC) is a world-leading R\&D and innovation hub in nano-electronics and digital technologies (see box X). It has 2 regular impact assessment processes.

The 2-year impact studies encompass all dimensions of impact: S\&T, economic, social/societal and catalytic (structuring effects).

The 5-year evaluation analysis includes an ex-post as well as an ex-ante component and addresses the following topics: how and to what extent IMEC fulfilled its mission and reached its objectives, what is the evolution compared to the previous evaluation period, what are the short-term and cumulative (over 10 years and more) multidimensional impacts of its activities and how does IMEC position itself internationally. The ex-ante part focuses on an analysis and assessment of the draft strategic plan for the next 5-year period. Thus the report, and in particular the impact assessment, play a key role in the Government's five-year strategic planning.

The general requirements to be met by IMEC (and the other Flemish strategic research centres) are: to achieve scientific excellence in an international context, to contribute to the implementation of the science and innovation policies of Flanders, and in particular to generate an optimal impact in the Flemish economic and societal fabric.

Impact indicators are included within IMEC KPIs and nine of those are currently used to monitor activities and reported annually (and in the 5-year strategic evaluation) since 2017:

- The excellence of IMEC is measured by: the number of peer reviewed publications; the number of first filings (patents); and the number of $\mathrm{PhD}$ students.

- The regional impact is measured by: the number of new spin-offs; the number of new iStart businesses; the income from collaboration with enterprises in the region; and the partnerships established with entities from the region.

- The multiplier effect on the resources received from the grant of the Flemish authority are measured by: the income from international programmes and the co-funding rate of the companies.

At the end of each year the KPIs are compared with the objectives that were set in advance. If the annual KPI targets are not achieved, the remaining annual balance (10\% of the grant) will only be partially paid out. IMEC must achieve eight out of nine KPIs to receive $100 \%$ of the grant.

\section{Monetising the results?}

As indicated in chapter 5.2, traditional cost-benefit analysis methodologies are difficult to apply on RIs. Nevertheless there is an increasing demand for assessing impact in monetary terms and there are a variety of methodologies for attributing financial value to impact. 
What is the RI producing in terms of return on investment is an obvious question from a policy perspective? Return on investment is particularly important in the case of RIs funded by multiple entities or countries. This "fair return" calculation often has a significant monetary aspect although non-monetary aspects, such as public utility, access and usage or reputation, can also be important.

A second and more challenging objective is to determine a financial value for the various impacts (and ultimately the global financial benefit a RI may provide to a region or country).

Despite the difficulty, it can be useful to monetise certain impacts, for example through a multiplier effect (Griniece, Reid and Angelis, 2015). From the framework proposed here, economic indicators like number of Full Time Equivalents within the RI (E34), total expenditures (E30), spin-offs (E37), number of visitors and users (E32), new tax payers (E33) and suppliers of the RI (E35) can be monetised through a multiplier effect. This multiplier effect can show an increase of national or regional income that arise from investment in an RI. As discussed throughout this report, the benefits can be multiple: innovation, production of science, regional influence etc. The multiplier effect shows how the RI impacts its local economy through an immediate economic impact - how the RI impacts local employment for example. Monetisation is easier to assess when the values of potential outcomes can be linked to market price, such as the number of suppliers of the RI.

RI managers wishing to monetise impacts have to be cautious: the numbers obtained may be useful for communicating to stakeholders and funders but can also be misleading. Over-estimation and under-estimation can both be risky. Furthermore, when multiplier effects occur, it may not be possible to reliably differentiate those directly linked to the RI activities to those from its local ecosystem and this methodology should therefore be restricted to well-known indicators within a well-defined context. ${ }^{7}$

When the use of multipliers is not possible, another technique which can be used is based on the use of counterfactual indicators such as the "willingness to pay" or the "willingness to forego". This approach has been used (although not without some discussion), for several RIs in the $\mathrm{UK}^{8}$ and can provide an evaluation of the financial value of RIs, although the actual robustness of the methodology is still controversial (see, for example, Florio and Sirtori, 2014). Another method involves questionnaires to people and interviews regarding how they value a given outcome. This technique is typically used to determine values related to environmental impact.

Choosing the right methodology for assessing and monetising impacts therefore depends on individual circumstances and on the level of analysis required by stakeholders. Monetisation describes only a part of an RI's impact and is often poor at taking into account scientific outputs, which are the main raison d'être for RIs. Monetising impacts should not be mandatory and when it is carried out the limitations on the results should be made clear. 


\section{Monetising RI impact: the IMEC experience}

Since 2005 IMEC and IDEA Consult (www.ideaconsult.be) collaborate to monitor the multidimensional impact of IMEC in Belgium. The model is centred around four different 'layers' of impact the scientific-technological impact of the institute, its economic impact, its catalytic impact in the broader tech start-up and scale up ecosystem and finally its additional society-wide impact. Over the years the impact model has been refined and adapted to reflect new realities and changing roles of IMEC in society.

In the analysis both quantitative and qualitative indicators are combined. Some dimensions of impact are being monetised while others are not. Specifically the following activities are being monetised:

- the value (in terms of added value, employment and fiscal return) of knowledge transfer to Belgian receivers through IMEC's contract research, interdisciplinary collective research (IMEC.icon), outflow of staff and training

- the economic footprint (in terms of added value, employment and fiscal return) of IMEC's and its spin-offs' regular business activities, expenditures and infrastructural investments in Belgium.

To estimate the economic leverage of these activities, a combination of methods is used:

- To estimate the economic leverage of IMEC's contract research, a technology multiplier based on research from Knell (2008) is used. This technology multiplier has been critically reviewed and updated by an expert panel in 2016, organised by IDEA Consult in the context of a study conducted on behalf of EARTO (European Association of RTO's). The technology multiplier is calculated on the basis of input-output tables.

- For the estimation of the economic leverage of IMEC's interdisciplinary collective research, an instrument specific multiplier is being calculated by IDEA Consult on the basis of a detailed portfolio-analysis of research projects in combination with an online survey and interviews with corporate research partners.

- The economic value of the outflow of IMEC staff to the Belgian economy is calculated as an average of two different calculations:

- The first method makes use of the average labour cost at IMEC, indicating the willingness to pay of enterprises for someone with an average 'IMEC employee' profile. This cost is multiplied by the Knell technology multiplier, as the actual value of the employee for the enterprise is more than the 'price' it pay;

- The second method does not apply the technology multiplier but uses the value added per employee (at IMEC) to measure the value of the knowledge transfer of personnel outflow.

- The calculation of the value of the knowledge transfer through training is based on the ratio 'value per hour of training'. This value is a combination of both the direct costs for the participants (registration fee + transport costs) and their opportunity cost (i.e. the time that the participant cannot work). This cost is again multiplied by the Knell technology multiplier to estimate the value of the knowledge transfer.

- Finally, to estimate the economic footprint of IMEC's and its spin-offs' regular business activities, expenditures and infrastructural investments in Belgium:

- The direct economic effect is measured based on data (on employment, turnover and added value) delivered by IMEC and the spin-offs. 
O Incoming invoices of IMEC are at the basis of the first order indirect effects calculations. The main advantage of using this type of information compared to national input-output-tables is that an institute specific multiplier for IMEC can be calculated. To calculate the effect further upstream (higher order effects), the latest input-output tables are being used.

- To estimate the induced economic effect, the figures on direct and indirect employment are used as the starting point. These are multiplied with average net wages in the different sectors where IMEC and the spin-offs create direct and indirect employment. Subsequently, these were multiplied with average wage-spending quota. Finally, the fraction of income that is spent outside Belgium is subtracted in order to arrive at net spending in the Belgian economy induced by IMEC's and its spin-offs' activities.

- Based on the direct, indirect and induced effect, one can estimate the fiscal and parafiscal return to the federal and regional governments in Belgium. This fiscal and parafiscal return is generated through the following channels: i) the social security contributions and wage tax thanks to the additional employment; ii) corporate taxes thanks to the additional output and iii) VAT thanks to the additional value added.

IDEA Consult and IMEC consciously choose for a conservative estimation in the monetisation of impact, to avoid double-counting and thus overestimation. The analysis is considered as producing objective and robust estimates of the economic leverage of IMEC on the Belgian economy - results that can be quoted as a lower boundary.

Sources: IDEA Consult 2017, 2018.

\section{Qualitative indicators and narratives}

Qualitative indicators involve information collections via dedicated and tailored methods such as surveys, semi-structured interviews or ECOUTER methodologies (Murthag et al., 2017) and case studies. They are an excellent way to complement quantitative data and provide useful insights on the different indicators and impacts listed in this framework.

This report proposes only a few qualitative indicators because they are more difficult to standardise: qualitative indicators need to be tailored for an RI and are very context dependent.

Narratives provide for a more comprehensive view of impact, using examples to illustrate progresses towards a specific goal/outcome. They are largely complementary to this framework. Using some of the indicators proposed in this framework, narratives can be produced: on topics such as sustainability, the effects of the RI on students' careers, or the RI's impact on local economy. Narratives can also be used to illustrate local and regional social and economic impacts of an RI based on concrete examples. 


\section{Conclusions}

This report proposes "A Reference Framework for assessing the scientific and socioeconomic impact of Research Infrastructures", i.e. a tool to help RIs of different scales, types and at different steps of their lifecycle to assess the impact of their activities. It includes different indicator groupings, constructed on the base of an in-depth survey of RI managers and stakeholders with research infrastructures and case studies:

- a table of Core Impact Indicators, fairly generic and related to RIs' strategic objectives

- a matrix articulating Core Impact Indicators with impact dimensions and strategic objectives

- a more comprehensive list of standard indicators.

While impact assessment represents an investment in terms of financial cost and human resources, it does provides all RI stakeholders, including funders and management with useful information to help improve performance and investment. It can also be a good way to communicate about RI activities with the general public.

As described throughout this report, a number of important elements have to be taken into account for an optimal use of this assessment framework:

- The link between strategic objectives and indicators is one of the major contributions of this work: The aim is it show how an RI achieves its goal through its whole set of activities.

- Although this report provides a number of representative indicators commonly used by RIs, none of these are mandatory. Each indicator should be carefully selected and adapted, as necessary, to the RI objectives and context, and the framework itself can be adapted and expanded as required.

- This framework is not designed for direct comparative assessment of different RIs. Even similar types of RIs may have different strategic objectives and missions and socio-economic impact is context-specific.

- Impacts often results from cumulative effects over time. As indicators usually only provide snapshot information at a given time, a more precise impact assessment can be generated by pooling data series, hence the need to use consistent indicators over time.

- Quantitative indicators, which constitute the majority of indicators included in this framework, can only provide a partial view of impact. They should be complemented whenever possible with more qualitative indicators and narratives which can help illustrate the diversity of impacts generated by each RI.

Based on the report's findings, the Expert Group offers the following recommendations to RI stakeholders:

- RI communities are encouraged to adopt and refine this assessment framework as a basis for impact assessment. They should seek consensus on the indicators which are most relevant for their RIs (and co-design new indicators if required) and on the specific data that could best inform each indicator. 
- RI management should define early in the RI life-cycle, their impact assessment framework and its future uses. Definition of data sources and collection processes is an important aspect of this as consistent data series are important for accuracy.

- RI stakeholders are invited to work with RI managers to define their needs for specific indicator data as well as the use in decision-making processes. Feasibility of data collection is an important consideration during this 'co-design' process. Where necessary (e.g. for small and medium-size RIs), funders should provide the necessary support for the data collection required to conduct robust impact assessment exercises. 


\section{Endnotes}

${ }^{1}$ This strategic objective was not part of the survey but emerged during discussion at the workshop. It appears that most RIs want some indicators to assess their level of exemplarity (on gender, equity, environment management, etc.).

${ }^{2}$ See "Using the framework" in chapter 6.3 and annex.

${ }^{3} \mathrm{Q} 1, \mathrm{Q} 2, \mathrm{Q} 3$ and Q4 journals can be presented differently but a generic definition can be found at http://ipscience-

help.thomsonreuters.com/inCites2Live/indicatorsGroup/aboutHandbook/usingCitationIndicatorsW isely/jifQuartile.html.

${ }^{4}$ In some cases, this can be extended as strategic objectives. However, it was not identified as such during our in-depth surveys.

${ }^{5}$ For distributed infrastructures, these CIIs concern the local nodes, not the whole research infrastructure. Indeed, each node can have a specific impact on its local area.

${ }^{6}$ Open data: resources freely available to everyone.

${ }^{7}$ In the UK, the HM Treasury "Green Book"

(https://assets.publishing.service.gov.uk/government/uploads/system/uploads/attachment_data/file/ 685903/The_Green_Book.pdf) does not promote the use of multipliers in estimates of social value.

8 The Value and Impact of Data Sharing and Curation: A synthesis of three recent studies of UK research data centres. 


\section{References}

Anselin, L., A. Varga and Z. Acs (1997), "Local geographic spillovers between university research and technology innovations", Journal of Urban Economics 42 Z(3), pp. 422-448, https://doi.org/10.1006/juec.1997.2032.

Arundel, A., G. Van de Paal and L. Soete (1995), PACE Report: Innovation Strategies of Europe's Largest Firms: Results of the PACE Survey for Information Sources, Public Research, Protection of Innovations, and Government Programmes. Final Report, MERIT, University of Limburg, Maastricht.

Autio, E., M. Bianchi-Streit and A.P. Hameri (2003), Technology Transfer and Technological Learning Through CERN's Procurement Activity, CENR 2003-005, CERN, Geneva. DOI: 10.5170/CERN2003-005.

Barratt, D., J. Wang and J. Binney (2016), Assessment of the Atlas of Living Australia's impact and value. Alluvium, $\quad$ https://www.csiro.au/en/About/Our-impact/Our-impact-in-action/Naturalenvironment/Atlas-of-Living-Australia.

Bianchi-Streit, M. et al. (1984), Economic utility resulting from CERN contracts (second study), CERN 84-14, CERN,

Genève, https://inis.iaea.org/collection/NCLCollectionStore/ Public/16/042/16042987.pdf.

Björling, S. (2018), Impact assessment, Perspectives from the Swedish Research Council, Head of the Department of Research Infrastructures The Swedish Research Council, OECD Workshop 19-20 March 2018.

Brottier, F. (2016), The socio-economic impact of research infrastructures: a generic evaluation framework and insights from selected case studies, Europportunities OÜ, https://indico.cern.ch/event/558880/contributions/2381524/attachments/1383157/2103580/17 BROT TIER F.pdf.

Callon, M. (1994), “Is science a public good?", Science, Technology and Human Values 19, pp. 345-424, https://doi.org/10.1177/016224399401900401.

COST Office, (2010), Benefits of Research Infrastructures beyond Science. The Example of the Square Kilometre Array (SKA), Final Report, https://stfc.ukri.org/files/impact-publications/benefits-ofresearch-infrastructures-beyond-science/.

Dasgupta, P. and P. David (1994). "Towards a new economics of science". Research Policy 23 (5), pp. 487-521. https://doi.org/10.1016/0048-7333(94)01002-1.

Drèze J.P. and N. Stern (1987), "The theory of cost-benefit analysis", in Auerbach A.J. and Feldstein M. (eds), Handbook of public economics, North Holland, Amsterdam, Vol. II.

EFDA, (2001), Cadarache as a European Site for ITER, Report on the technical and Socio-economic aspects, http://www-fusion-magnetique.cea.fr/site/rapport2001/ess1-full.pdf.

ESFRI (2017), Long-term sustainability of research infrastructures, ESFRI Scripta Volume II, https://www.esfri.eu/sites/default/files/u4/ESFRI SCRIPTA TWO PAGES 19102017 3.pdf.

European Spallation Source, (2018), First socio-economic impact assessment, Final report.

Florio, M. et al. (2016), "Exploring Cost-Benefit Analysis of Research, Development and Innovation Infrastructures: An Evaluation Framework." Center for Industrial Studies Working Paper N. 01/2016, https://arxiv.org/pdf/1603.03654.pdf. 
Florio, M., S. Forte and E. Sirtori (2016), "Forecasting the socio-economic impact of the Large Hadron Collider: A cost-benefit analysis to 2025 and beyond", Technological Forecasting and Social Change, Vol 112, pp. 38-53, https://doi.org/10.1016/j.techfore.2016.03.007.

Florio, M. and E. Sirtori (2014), "The evaluation of research infrastructures: a cost-benefit analysis framework", Milan European Economy Workshops, Jean Monnet Chair, Working paper n. 2014-10, https://papers.ssrn.com/sol3/papers.cfm?abstract id=2722500.

Godin, B. and C. Doré (2014), Measuring the Impact of Science: Beyond the Economic Dimension, Draft, http://www.csiic.ca/PDF/Godin_Dore_Impacts.pdf.

Gramlich, E.M. (1994), "Infrastructure Investment: A Review Essay", Journal of Economic Literature, Vol. 32 (3): pp. 1176- 1196, https://www.jstor.org/stable/2728606.

Griliches, Z. (1995), "R\&D and productivity" in Handbook of Industrial Innovation. Blackwell, London, pp. 52-89.

Griniece E., A Reid and J. Angelis (2015), Guide to Evaluating and Monitoring Socio-Economic Impact of Investment in Research Infrastructures. Technopolis Group. Tallinn. Estonia, http://www.technopolis-group.com/wp-

content/uploads/2015/04/2015_Technopolis_Group_guide_to_impact_assessment_of_research_infras tructures.pdf.

Hallin, E. (2012), Economic, Societal and technological impact of large scale research facilities, Canadian Light Source Inc, European Research Facilities Workshop, https://indico.desy.de/indico/event/5340/session/1/material/slides/0? contribId=6.

Hallonsten, O. and T. Heinze (2012), "Institutional persistence through gradual adaptation: Analysis of national laboratories in the USA and Germany". Science and Public Policy, 39, pp. 450-463, https://doi.org/10.1093/scipol/scs047.

Hallonsten, O. (2014), "The politics of European collaboration in big science” in M. Mayer, M. Carpes, \& R. Knoblich (Eds.), International relations and the global politics of science and technology. Dordrecht: Springer, pp. 31-46.

Hallonsten O. and O. Christensson (2017), An ex-post impact study of Max-lab, Lund University School of Economics and Management, University, http://portal.research.lu.se/portal/en/publications/an-ex-post-impact-study-of-maxlab(ab1e7aa7-add54938-b21b-c6058b909682).html.

Horlings, E. et al. (2012), "The societal footprint of big science”, Rathenau Instituut, Working paper 1206, https://www.researchgate.net/publication/266513583_The_societal_footprint_of_big_science.

Jaffe, A. (1989), "Real effects of academic research". American Economic Review 79(5), pp. 957-970, https://www.jstor.org/stable/1831431.

Jimenez, R.C. (2017), ELIXIR KPI framework and alignment of KPIs between e-Infrastructures and research infrastructures, e-IRG workshop June 2017, http://eirg.eu/documents/10920/382077/ELIXIR+indicators+-+Rafael+C+Jimenez.pdf.

Katz, J.S. (1994), “Geographical proximity and scientific collaboration”, Scientometrics 31(1), pp. 31-43, https://doi.org/10.1007/BF02018100.

Knell M. (2008), "Product-embodied technological diffusion and intersectoral linkages in Europe", https://www.researchgate.net/publication/265369750_Productembodied_technological_diffusion_and_intersectoral_linkages_in_Europe. 
Kolarz, P. et al. (2017), Comparative impact study of the European Social Survey (ESS) ERIC Final report, Technopolis Group, pp. 134, https://www.europeansocialsurvey.org/docs/findings/ESS-Impact-studyFinal-report.pdf.

Li, C.W. (2002), "Growth and scale effects: the role of knowledge spillovers", Economic Letters, 74, pp. 177-185, https://doi.org/10.1016/S0165-1765(01)00542-0.

Marsili, O. (2001), The anatomy and evolution of industries: technical change and industrial dynamics, Edward Elgard Publishing, Cheltenham.

Martin, B. et al. (1996), The Relationship Between Publicly Funded Basic Research and Economic Performance, SPRU, Science Policy Research Unit, University of Sussex, https://www.researchgate.net/publication/242087185_THE_RELATIONSHIP_BETWEEN_PUBLIC LY_FUNDED_BASIC_RESEARCH.

Moed H.F., M. Luwel and C. Daraio (2014), Scientometrics as Big Data Science: On integration of data sources and the problem of different types of classification systems, OECD Workshop, Paris, 25 March, http://www.oecd.org/sti/inno/4.2.\%20Henk\%20Moed.pdf.

Murthag M. J. (2017), "The ECOUTER methodology for stakeholder engagement in translational research", BMC Medical Ethics, BMC series - open, inclusive and trusted 2017 18:24, https://doi.org/10.1186/s12910-017-0167-z.

OECD (2015), Frascati Manual 2015: Guidelines for Collecting and Reporting Data on Research and Experimental Development, The Measurement of Scientific, Technological and Innovation Activities, OECD Publishing, Paris, http://dx.doi.org/10.1787/9789264239012-en

OECD (2014), The Impacts of Large Research Infrastructures on Economic Innovation and on Society: Case Studies at CERN, http://www.oecd.org/sti/inno/CERN-case-studies.pdf.

Pilar G. (2012), An Analysis of the socio-economic impact of African-European research infrastructure cooperation, Promoting African European Research Infrastructure Partnerships, Seventh framework programme, PAERIP, https://slideplayer.com/slide/5909292/.

Prettner, K. and K. Werner (2016), "Why it pays off to pay us well: The impact of basic research on economic growth and welfare", Research policy, $\mathrm{N}^{\circ} 45(5)$, pp. 1075-1090, https://doi.org/10.1016/j.respol.2016.03.001

PwC (2016), Study to examine the socio-economic impact of Copernicus in the EU, Report on The socio-economic impact of the Copernicus programme, Final Report, http://cop.fdc.fr/sites/default/files/library/Copernicus_Report_Downstream_Sector_October_2016.pdf

Rizzuto, C. (2012), The various dimensions of impacts and of related stakeholders, Socio-economic relevance of research infrastructures, Presentation at European Association of National Research Facilities Open to International Access, Hamburg, https://erf.desy.de/sites2009/site_erf/content/e99281/e112179/infoboxContent116075/Booklet.pdf.

Rochow, R. et al. (2011), Foresight enriched Research Infrastructure Assessment Methodology (fenRIAM), https://www.researchgate.net/publication/236645351_FenRIAM_full_guide_Proposal_for_a_Foresig ht-enriched Research Infrastructure Impact assessment Methodology.

Rosenberg, S.R. (1992), The social impact of computers, First Edition, Academic Press.

Saler, A.J. and B.R. Martin (2001), "The economic benefits of publicly funded basic research: a critical review”, Research Policy 30(3), pp. 509-532, https://doi.org/10.1016/S0048-7333(00)00091-3.

Senker, J. (1995), Tacit knowledge and models of innovation. Industrial and Corporate Change 4(2), pp. 425-447. DOI: 10.1093/icc/4.2.425. 
STFC (2014), Impact Framework and Evaluation Strategy, Science and Technology Facilities Council, http://www.stfc.ac.uk/stfc/cache/file/B5D5D5C7-809A-44F3-990FBDC045835BAC.pdf.

The TORI Group (2013), Nasa Socio-Economic Impact, Final report for NASA, https://www.nasa.gov/sites/default/files/files/SEINSI.pdf.

TRIUMF (2013), Return on Investment in Large Scale Research Infrastructure, Final report for the National Research Council Canada, https://www.triumf.ca/sites/default/files/HALReturnOnInvestmentStudy-May-2013.pdf. 


\section{Appendices}

\subsection{Appendix 1. Expert Group Members}

\begin{tabular}{|c|c|c|}
\hline COUNTRY & NAME & ORGANISATION \\
\hline Australia & Michelle Barker & Australian Research Data Commons \\
\hline Czech Republic & Jan Hrušák & Academy of Sciences + ESFRI \\
\hline $\begin{array}{l}\text { European } \\
\text { Union }\end{array}$ & Keji Adunmo & $\begin{array}{l}\text { DG Research \& Innovation } \\
\text { Unit B4 - Research Infrastructure }\end{array}$ \\
\hline France (chair) & Vincent Mangematin & Kedge Business School \\
\hline Italy & Lucilla Alagna & CNR \\
\hline \multirow{2}{*}{ Japan } & Takashi Nakagawa & JST (now moved to Prime minister cabinet office) \\
\hline & Motoo Ito & $\begin{array}{l}\text { Japan Agency for Marine-Earth Science and Technology } \\
\text { (JAMSTEC) }\end{array}$ \\
\hline \multirow{2}{*}{ Korea } & Man Hyung Cho & Hannam University \\
\hline & Sun Kun Oh & Konkuk University \\
\hline South Africa & Kevin Govender & International Astronomical Union \\
\hline \multirow{2}{*}{ Sweden } & Sofie Björling & Swedish Research Council \\
\hline & Magnus Friberg & Swedish Research Council \\
\hline Switzerland & Martin Pohl & University of Geneva \\
\hline \multirow{2}{*}{ UK } & Claire Dougan & STFC \\
\hline & Lucy Hackett & STFC \\
\hline USA & Joshua L. Rosenbloom & Department of Economics, Iowa State University \\
\hline EIROforum & Frédéric Le Pimpec & European XFEL GmbH \\
\hline EFIS & Jelena Angelis & European Future Innovation System Centre \\
\hline
\end{tabular}




\begin{tabular}{|l|l|l|}
\hline \multirow{4}{*}{ Technopolis } & Paul Simmonds & Technopolis UK \\
\cline { 2 - 3 } & Elisabeth Zaparucha & Technopolis France \\
\hline \multirow{4}{*}{ OECD } & Frédéric Sgard & GSF Secretariat \\
\cline { 2 - 3 } & Carthage Smith & GSF Secretariat \\
\cline { 2 - 3 } & Taro Matsubara & GSF Secretariat \\
\cline { 2 - 3 } & Jean Moulin & Consultant \\
\cline { 2 - 3 } & Frédéric Bally & Consultant \\
\hline
\end{tabular}




\subsection{Appendix 2. Research infrastructures surveyed}

A representative sample of 21 RIs was surveyed for which the responses of the RI Managers were received. The survey comprised the completion of a comprehensive written questionnaire (with iterations where appropriate) followed by telephone interviews.

[Detailed results from the surveys are available at https://community.oecd.org/docs/DOC146805]

\section{RIs surveyed:}

European Synchrotron Radiation Facility (ESRF) (international)

Australian Synchrotron (Australia)

Diamond Light source (UK)

Centre for Functional Nanomaterials (CFN) (US)

International Thermonuclear Experimental Reactor (ITER) (international)

National Fusion Research Institute (Korea)

Sudbury Neutrino Observatory Laboratory (SNOLAB) (Canada)

Pierre Auger Observatory (International)

Square Kilometer Array (SKA) (International)

National Astronomical Observatory of Japan Subaru Telescope (Japan)

Entoto Observatory Research Center (EORC) (Ethiopia)

National Astronomical Research Institute of Thailand (NARIT) (Thailand)

European life-sciences Infrastructure for biological Information (ELIXIR) (International)

European Advanced Translational Research Infrastructure in Medicine (EATRIS)

(International)

International Mouse Phenotype Consortium (IMPC) (International)

European Marine Biological Research Centre (EMBRC) (International)

Research Icebreaker Polarstern (Germany)

European contribution to the global Argo ocean observations network (EURO-ARGO)

(International)

Atlas of Living Australia (ALA) (Australia)

European Social Survey (ESurvey) (International)

Consortium of European Social Science Data Archives (CESSDA) (International)

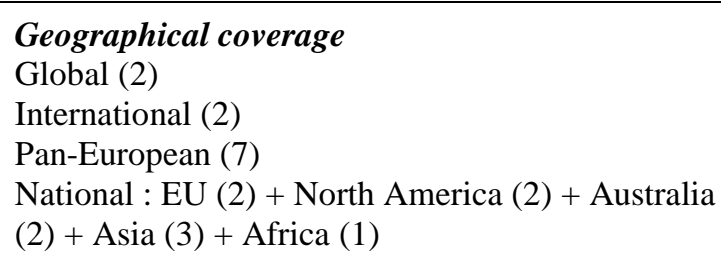

\section{Lifecycle}

Operation (Op) (10)

Operation + major upgrade (Up) (3)

Operation + in development (Dev) (6)

Construction (Constr)(2)

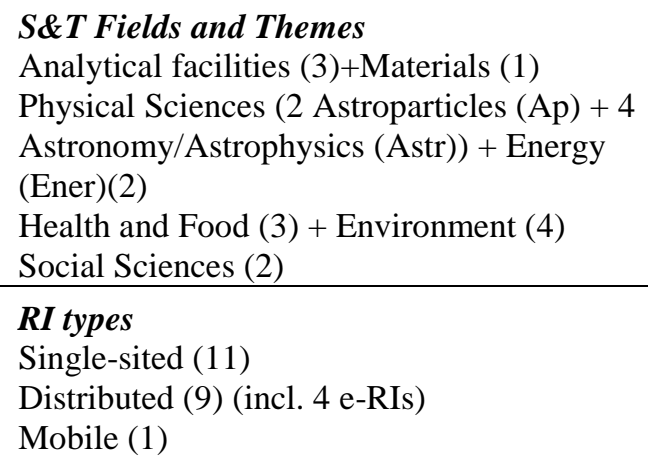

Responses from external stakeholders (policy makers, funders, host organisations and local authorities) were also received for a subset of 14 RIs. 


\begin{tabular}{|c|c|c|c|c|c|c|c|c|c|c|c|c|c|c|c|c|c|c|c|}
\hline \multirow{2}{*}{$\begin{array}{l}\text { RI MANAGERS } \\
\text { (21 RIS) }\end{array}$} & \multirow{2}{*}{$\begin{array}{l}\bar{\pi} \\
\frac{0}{0} \\
\text { 흉 }\end{array}$} & \multirow{2}{*}{ 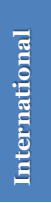 } & \multirow{2}{*}{ 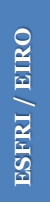 } & \multirow{2}{*}{ 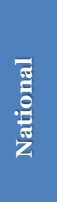 } & \multirow{2}{*}{ 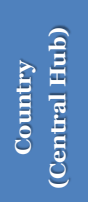 } & \multirow{2}{*}{ 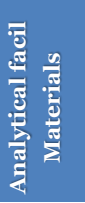 } & \multirow{2}{*}{ 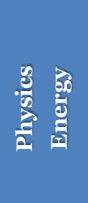 } & \multirow{2}{*}{ 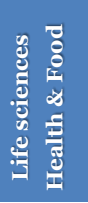 } & \multirow{2}{*}{ 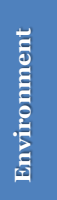 } & \multirow{2}{*}{$\frac{\sqrt{5}}{5}$} & \multirow{2}{*}{ 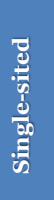 } & \multirow{2}{*}{ 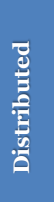 } & \multirow{2}{*}{ 离 } & \multirow{2}{*}{$\frac{0}{3}$} & \multirow{2}{*}{$\begin{array}{l}\frac{0}{2} \\
\frac{0}{5} \\
\frac{0}{0}\end{array}$} & \multicolumn{4}{|c|}{$\begin{array}{l}\text { EXTERNAL STAKEHOLDERS } \\
\text { (14 RIS) }\end{array}$} \\
\hline & & & & & & & & & & & & & & & & ठे & 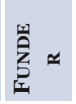 & 药 & క్తુ \\
\hline ESRF & & $\mathrm{x}$ & $\mathrm{x}$ & & FR & $\mathrm{x}$ & & & & & $\mathrm{x}$ & & & & $\mathrm{Op} / \mathrm{Up}$ & & & & \\
\hline AUSTRALIAN SR & & & & $\mathrm{x}$ & $\mathrm{AU}$ & $\mathrm{x}$ & & & & & $\mathrm{x}$ & & & & Oper & & & $\mathrm{Y}$ & $\mathrm{Y}$ \\
\hline DLAMOND & & & & $\mathrm{x}$ & UK & $\mathrm{x}$ & & & & & $\mathrm{x}$ & & & & Oper & & Y & Y & \\
\hline CFN & & & & $\mathrm{x}$ & US & Mat & & & & & $\mathrm{x}$ & & & & Oper & & & & \\
\hline ITER & $\mathrm{x}$ & & & & FR & & Ener & & & & $\mathrm{x}$ & & & & Constr & & & & \\
\hline NFRI & & & & $\mathrm{x}$ & KR & & Ener & & & & $\mathrm{x}$ & & & & Oper & & & & \\
\hline SNOLAB & & & & $\mathrm{x}$ & $\mathrm{CA}$ & & $\mathrm{AP}$ & & & & $\mathrm{x}$ & & & & $\mathrm{Op} / \mathrm{Up}$ & & & & Y \\
\hline AUGER & & $\mathrm{x}$ & & & AR & & $\mathrm{AP}$ & & & & $\mathrm{x}$ & & & & $\mathrm{Op} / \mathrm{Up}$ & & & & Y \\
\hline SKA & $\mathrm{x}$ & & $\mathrm{x}$ & & UK & & Astro & & & & & $\mathrm{x}$ & & & Constr & Y & & & \\
\hline NAOJ SUBARU & & & & $\mathrm{x}$ & JP & & Astro & & & & $\mathrm{x}$ & & & & Oper & Y & & & \\
\hline EORC & & & & $\mathrm{x}$ & ET & & Astro & & & & $\mathrm{X}$ & & & & Oper & & & & \\
\hline NARIT & & & & $\mathrm{x}$ & ТH & & Astro & & & & $\mathrm{X}$ & & & & Oper & & & & \\
\hline ELIXIR & & $\mathrm{x}$ & $\mathrm{x}$ & & UK & & & $\mathrm{x}$ & & & & $\mathrm{x}$ & & $\mathrm{x}$ & Op/Dev & & & Y & \\
\hline EATRIS & & $\mathrm{x}$ & $\mathrm{x}$ & & NL & & & $\mathrm{x}$ & & & & $\mathrm{x}$ & & & Op/Dev & & Y & & \\
\hline IMPC & & $\mathrm{x}$ & & & US & & & $\mathrm{x}$ & & & & $\mathrm{x}$ & & & Oper & & Y & & \\
\hline EMBRC & & $\mathrm{x}$ & $\mathrm{x}$ & & FR & & & (X) & $\mathrm{x}$ & & & $\mathrm{x}$ & & & Op/Dev & & & & \\
\hline POLARSTERN & & & & $\mathrm{x}$ & $\mathrm{DE}$ & & & & $\mathrm{x}$ & & & & $\mathrm{x}$ & & Oper & & Y & & Y \\
\hline EuroARGO & & $\mathrm{x}$ & $\mathrm{x}$ & & FR & & & & $\mathrm{x}$ & & & $\mathrm{x}$ & & & Op/Dev & $\mathrm{Y}$ & & & \\
\hline ALA & & & & $\mathrm{x}$ & $\mathrm{AU}$ & & & & $\mathrm{x}$ & & & $\mathrm{x}$ & & $\mathrm{x}$ & Oper & $\mathrm{Y}$ & & & \\
\hline ESSurvey & & $\mathrm{X}$ & $\mathrm{x}$ & & UK & & & & & $\mathrm{x}$ & & $\mathrm{x}$ & & $\mathrm{x}$ & $\mathrm{Op} / \mathrm{Dev}$ & & & $\mathrm{Y}$ & \\
\hline CESSDA & & $\mathrm{X}$ & $\mathrm{x}$ & & NO & & & & & $\mathrm{X}$ & & $\mathrm{x}$ & & $\mathrm{X}$ & $\mathrm{Op} / \mathrm{Dev}$ & & & Y & \\
\hline
\end{tabular}




\subsection{Appendix 3. Core Impact Indicators and their relevance according to RIs' lifecycle and types}

\section{Relevance of CII:}

Each CII is linked to a strategic objective in the following table.

However, the usefulness and the relevance of these CIIs can be different according to the RIs' lifecycle and to the type of activity carried out by the RI. To help managers and stakeholders to select their CII, we propose in Table 5 below a color code according to the relevance. This table has been submitted to different RIs during the case studies in order to have feedback on the relevance of each CII at different steps of the RIs' lifecycle.

\section{Types of RIs:}

Although CIIs are designed to be usable for most RIs, the relevance of each CII may also be variable according to the RI type. In Table 5, we have classified RIs according to three main categories:

- Research performing RI (noted as Type 1 in Table 5):

These are RIs at which research is being carried out either by RI scientists or by scientific users using data produced by the RI instruments. They can be subdivided into:

- Experimental facilities (e.g. particle accelerators, analytical facilities, biomedical facilities, etc.)

- Observational platforms (e.g. telescopes, environmental observatories, etc.).

- Equipment provider RI (noted as Type 2 in Table 5):

These are RIs which provide technological/testing/instrumental/ICT resources and services (e.g. support to technological development, innovation, demonstration, prototyping, HPC).

- Data/specimen resource (noted as Type 3 in Table 5):

These are RIs that provide access to data or to sample collections to users, often through a central portal connected to distributed nodes. They can be subdivided into:

- Data-oriented infrastructures

- Specimen collections (Biobanks, biological archives).

These three categories are not mutually exclusive and some large international infrastructures may fall within all 3 categories.

\section{Colour code for Table 5}

\begin{tabular}{|l|l|}
\hline & Not relevant \\
\hline & low \\
\hline & medium \\
\hline & high \\
\hline & Very high \\
\hline
\end{tabular}


Table 5. Example of Core Impact Indicators, sorted by their lifecycle relevance and RI type

\begin{tabular}{|c|c|c|c|}
\hline CII & Planning/Construction & Operation/Upgrading & RI type \\
\hline \multicolumn{4}{|c|}{ Be a world/regional/national scientific leading $R I$ and an enabling facility to support science } \\
\hline \multirow{3}{*}{$\begin{array}{l}\text { S2- Number of } \\
\text { citations }\end{array}$} & & & 1 \\
\hline & & & 2 \\
\hline & & & 3 \\
\hline \multirow{3}{*}{$\begin{array}{l}\text { S3- Number of } \\
\text { publications in High } \\
\text { Impact factor journals }\end{array}$} & & & 1 \\
\hline & & & 2 \\
\hline & & & 3 \\
\hline \multirow{3}{*}{$\begin{array}{l}\text { S4- Number of projects } \\
\text { granted }\end{array}$} & & & 1 \\
\hline & & & 2 \\
\hline & & & 3 \\
\hline \multirow{3}{*}{$\begin{array}{l}\text { S6- Number of } \\
\text { scientific users }\end{array}$} & & & 1 \\
\hline & & & 2 \\
\hline & & & 3 \\
\hline \multirow{3}{*}{$\begin{array}{l}\text { S9- Collaboration } \\
\text { excellence (scientific) }\end{array}$} & & & 1 \\
\hline & & & 2 \\
\hline & & & 3 \\
\hline \multirow{3}{*}{$\begin{array}{l}\text { S10- Structuring } \\
\text { effects of the RI on the } \\
\text { scientific community }\end{array}$} & & & 1 \\
\hline & & & 2 \\
\hline & & & 3 \\
\hline \multicolumn{4}{|c|}{ Be an enabling facility to support innovation } \\
\hline \multirow{3}{*}{$\begin{array}{l}\text { T18- Patent } \\
\text { with a commercial use }\end{array}$} & & & 1 \\
\hline & & & 2 \\
\hline & & & 3 \\
\hline \multirow{3}{*}{$\begin{array}{l}\text { T20- Innovations co- } \\
\text { developed with } \\
\text { industry }\end{array}$} & & & 1 \\
\hline & & & 2 \\
\hline & & & 3 \\
\hline \multirow{3}{*}{$\begin{array}{l}\text { T24- Collaborative } \\
\text { projects with industrial } \\
\text { partners }\end{array}$} & & & 1 \\
\hline & & & 2 \\
\hline & & & 3 \\
\hline \multicolumn{4}{|c|}{$\begin{array}{c}\text { Become integrated in a regional cluster/in regional strategies / Be a hub to facilitate regional } \\
\text { collaborations }\end{array}$} \\
\hline \multirow{3}{*}{$\begin{array}{l}\text { E34- Number of Full } \\
\text { time equivalent within } \\
\text { the RI }\end{array}$} & & & 1 \\
\hline & & & 2 \\
\hline & & & 3 \\
\hline \multirow{3}{*}{$\begin{array}{l}\text { S11- Papers co- } \\
\text { authored with regional } \\
\text { universities }\end{array}$} & & & 1 \\
\hline & & & 2 \\
\hline & & & 3 \\
\hline \multirow{3}{*}{$\begin{array}{l}\text { T25- Regional firms } \\
\text { using the RI facilities }\end{array}$} & & & 1 \\
\hline & & & 2 \\
\hline & & & 3 \\
\hline \multirow{3}{*}{$\begin{array}{l}\text { E35- Number of local / } \\
\text { regional suppliers }\end{array}$} & & & 1 \\
\hline & & & 2 \\
\hline & & & 3 \\
\hline
\end{tabular}




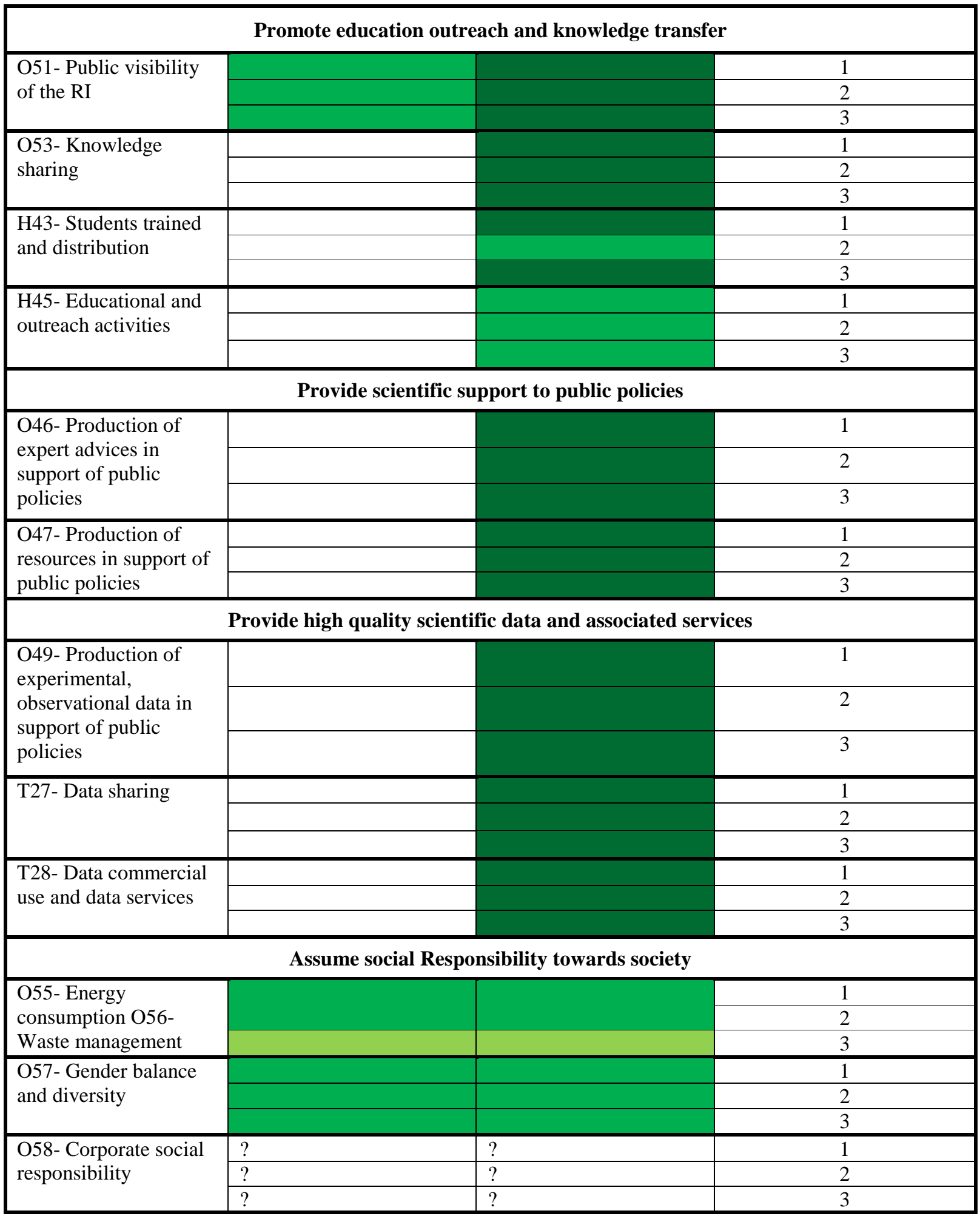




\subsection{Appendix 4. Indicators sorted by strategic objectives}

Table 6. Final list of indicators

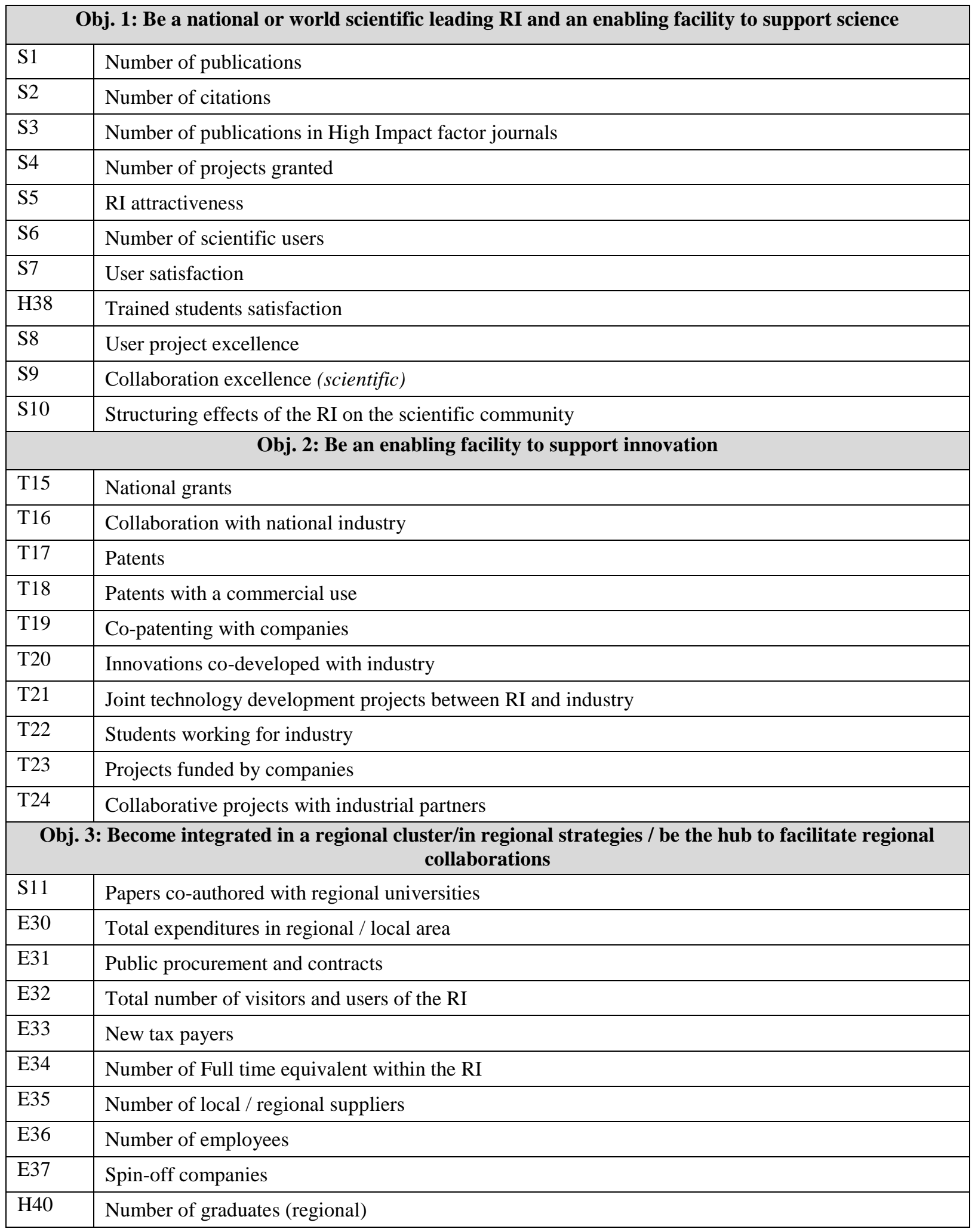




\begin{tabular}{|c|c|}
\hline $\mathrm{T} 25$ & Regional firms using the RI facilities \\
\hline T26 & Collaborative projects with regional industrial partners \\
\hline \multicolumn{2}{|r|}{ Obj. 4: Promote education outreach and knowledge diffusion } \\
\hline O50 & Public awareness \\
\hline O51 & Public visibility of the RI \\
\hline $\mathrm{O} 52$ & Popularity of the RI (public and users) \\
\hline $\mathrm{O} 53$ & Knowledge sharing \\
\hline S12 & Use and production of open data \\
\hline O54 & Openness to public \\
\hline H41 & Career of students trained within the RI \\
\hline $\mathrm{H} 42$ & Grants for trainees \\
\hline $\mathrm{H} 43$ & Students trained and distribution \\
\hline H44 & Training programs for High School students \\
\hline $\mathrm{H} 45$ & Educational and outreach activities \\
\hline \multicolumn{2}{|r|}{ Obj. 5: Provide scientific support to public policies } \\
\hline $\mathrm{O} 46$ & Production of expert advices in support of public policies \\
\hline $\mathrm{O} 47$ & Production of resources in support of public policies \\
\hline $\mathrm{O} 48$ & Contribution of the RI researchers to Public Policies \\
\hline \multicolumn{2}{|r|}{ Obj. 6: Provide high quality scientific data and associated services } \\
\hline $\mathrm{O} 49$ & Production of experimental, observational data in support of public policies \\
\hline $\mathrm{T} 27$ & Data sharing \\
\hline $\mathrm{T} 28$ & Data commercial use and data services \\
\hline T29 & Data usage \\
\hline H39 & Use of the data for training \\
\hline $\mathrm{S} 13$ & Data openness \\
\hline S14 & Digital resource openness \\
\hline \multicolumn{2}{|r|}{ Obj. 7: Social responsibility } \\
\hline $\mathrm{O} 55$ & Energy consumption \\
\hline O56 & Waste management \\
\hline O57 & Gender balance and diversity \\
\hline $\mathrm{O} 58$ & Corporate social responsibility \\
\hline
\end{tabular}

